University of Rhode Island

DigitalCommons@URI

Open Access Master's Theses

1986

ROLE OF VASCULAR REACTIVITY AND COLLAGEN

BIOSYNTHESIS IN THE DEPRESSOR EFFECT OF STREPTOZOTOCIN IN THE SPONTANEOUSLY HYPERTENSIVE RAT

Paul H. Breault

University of Rhode Island

Follow this and additional works at: https://digitalcommons.uri.edu/theses

Recommended Citation

Breault, Paul H., "ROLE OF VASCULAR REACTIVITY AND COLLAGEN BIOSYNTHESIS IN THE DEPRESSOR EFFECT OF STREPTOZOTOCIN IN THE SPONTANEOUSLY HYPERTENSIVE RAT" (1986). Open Access Master's Theses. Paper 182.

https://digitalcommons.uri.edu/theses/182

This Thesis is brought to you for free and open access by DigitalCommons@URI. It has been accepted for inclusion in Open Access Master's Theses by an authorized administrator of DigitalCommons@URI. For more information, please contact digitalcommons-group@uri.edu. 


\section{ROLE OF VASCULAR REACTIVITY AND COLLAGEN BIOSYNTHESIS IN THE DEPRESSOR EFFECT OF STREPTOZOTOCIN IN THE SPONTANEOUSLY HYPERTENSIVE RAT}

BY PAUL H. BREAULT

A THESIS SUBMITTED IN PARTIAL FULFILLMENT OF THE REQUIREMENTS FOR THE DEGREE OF MASTER OF SCIENCE IN

PHARMACOLOGY AND TOXICOLOGY

UNIVERSITY OF RHODE ISLAND 


\section{MASTER OF SCIENCE THESIS}

of

Paul H. Breault

Approved:

Thes is Committee:

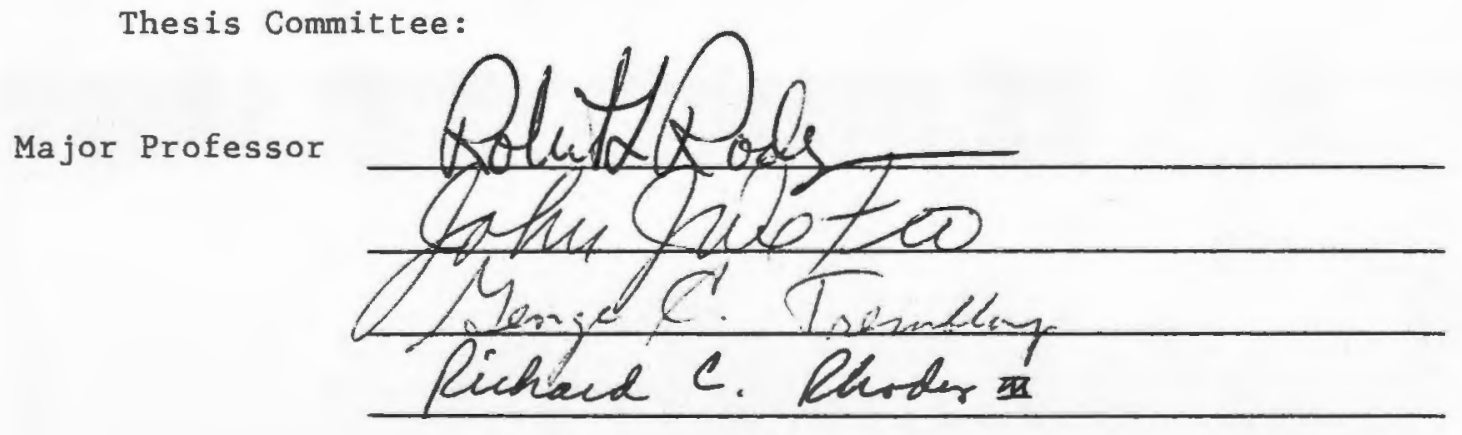

A.M. hichel

Dean of the Graduate School

UNIVERSITY OF RHODE ISLAND 


\section{ABSTRACT}

Diabetes decreases systolic arterial pressure in the spontaneously hypertensive rat (SHR). Two possible mechanisms, a decrease in vascular collagen biosynthesis and an altered vascular reactivity, were investigated. Collagen biosynthesis, as indicated by prolyl hydroxylase activity, was reduced in the aorta in the diabetic SHR to a greater extent than the diabetic Wistar-Kyoto rat (WKY). Prolyl hydroxylase activity was also reduced, but to a lesser extent, in the aorta of food restricted and hypothyroid SHR and WKY rats. Streptozotocin (STZ)-induced diabetes increased the sensitivity of the mesenteric artery of both strains to methoxamine only. The response of the mesenteric artery of the SHR was increased, though not significantly, to norepinephrine and methoxamine. Therefore, it appears that the depressor effect of STZ in the SHR is not associated with a reduction in vascular reactivity. The results suggest that a reduction in collagen synthesis may play a role in the depressor effect of STZ in the SHR. The reduction in collagen biosynthesis in $\mathrm{STZ}$-induced diabetes may in part be due to the altered nutritional state and a reduction in thyroid hormones associated with diabetes. 
TABLE OF CONTENTS

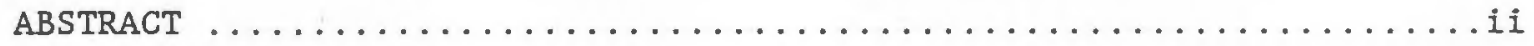

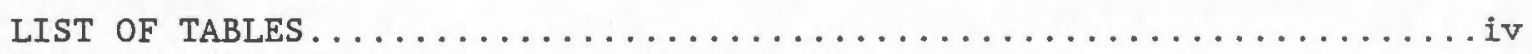

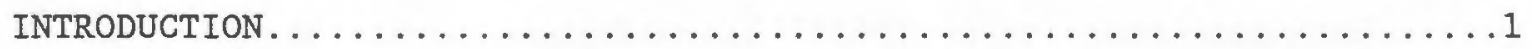

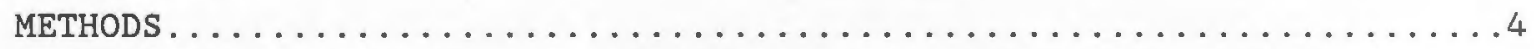

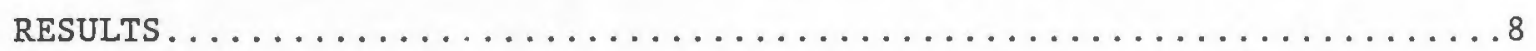

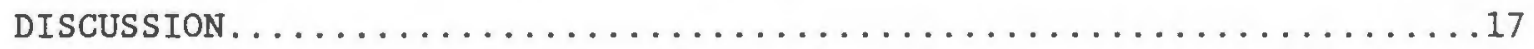

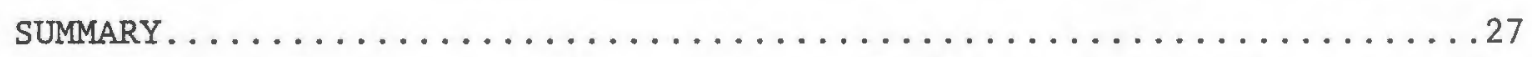

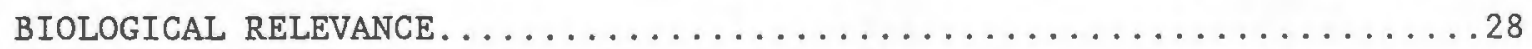

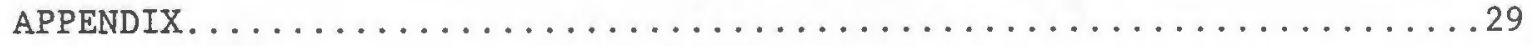

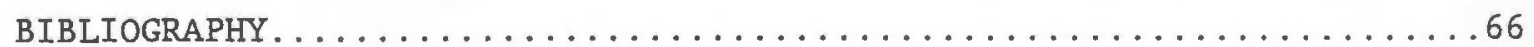


LIST OF TABLES

1. Effect of STZ-induced Diabetes ( 8 weeks) on Body Weight, Food Intake, Water Intake and Urine Output..............11

2. Effect of STZ-induced Diabetes ( 8 weeks) and of Food Restriction and Hypothyroidism on Serum Glucose, Insulin and $T_{4}$ of SHR and

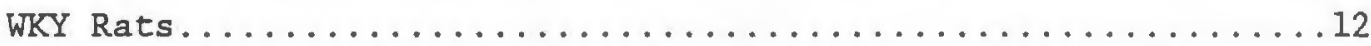

3. Effect of STZ-induced Diabetes ( 8 weeks) and of Food Restriction on Systolic Arterial Pressure (SAP) of SHR and WKY Rats......13

4. Effect of STZ-induced Diabetes (8weeks) and Food Restriction on Prolyl Hydroxylase Activity in the Aorta of the SHR and

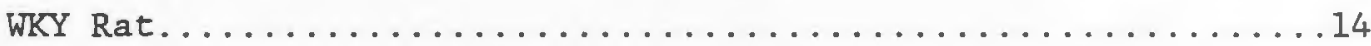

5. Effect of Hypothyroidism on Prolyl Hydroxylase Activity in the

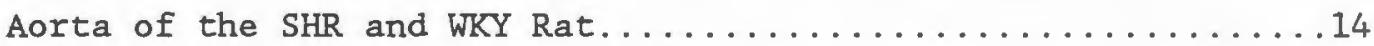

6. Effect of STZ-induced Diabetes (8 weeks) and of Food Restriction and Hypothyroidism on Sensitivity $\left(\mathrm{pD}_{2}\right)$ of the Mesenteric

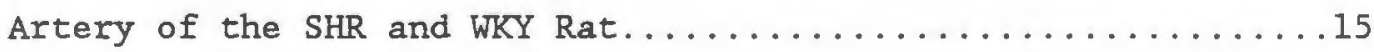

7. Effect of STZ-induced Diabetes ( 8 weeks) and of Food Restriction and Hypothyroidism on Responsiveness of the Mesenteric Artery

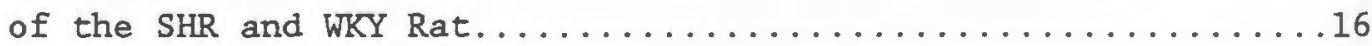

8. Prolyl Hydroxylase Distillation Recovery....................29

9. Lowry Protein Assay. Test for Interference of Tissue

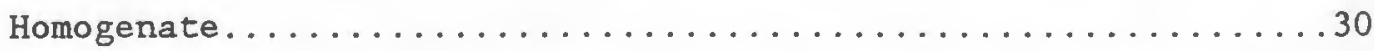

10. Effect of STZ-induced Diabetes on Body Weight of the SHR and

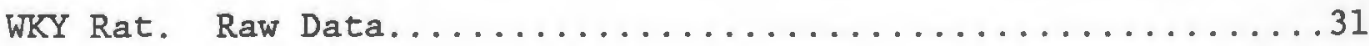




\section{LIST OF TABLES Continued}

11. Effect of STZ-induced Diabetes on the Food Consumption of the

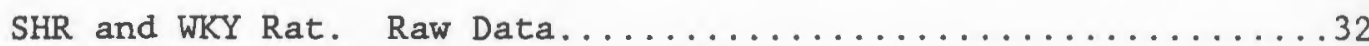

12. Effect of STZ-induced Diabetes on the Water Consumption of the

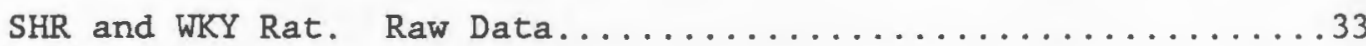

13. Effect of STZ-induced Diabetes on the Urine Production of the

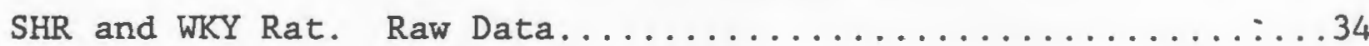

14. Effect of STZ-induced Diabetes and of Food Restriction and Hypothyroidism on Serum Glucose of the SHR and WKY Rat.

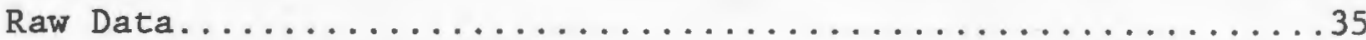

15. Effect of STZ-induced Diabetes and of Food Restriction and Hypothyroidism on Serum Insulin of the SHR and WKY Rat.

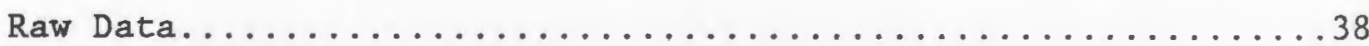

16. Effect of STZ-induced Diabetes and of Food Restriction and Hypothyroidism on Serum Thyroxine $\left(\mathrm{T}_{4}\right)$ of the SHR and WKY

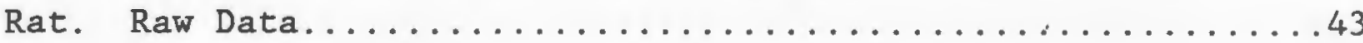

17. Effect of STZ-induced Diabetes and Food Restriction on Systolic Arterial Pressure (SAP) of the SHR and WKY Rat. Raw Data.....48

18. Effect of STZ-induced Diabetes and of Food Restriction and Hypothyroidism on Prolyl Hydroxylase Activity in the Aorta

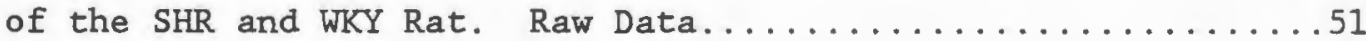

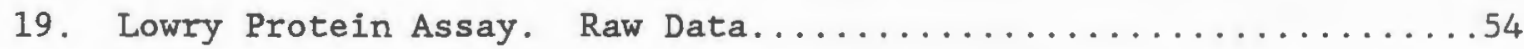

20. Effect of STZ-induced Diabetes and of Food Restriction and Hypothyroidism on the Sensitivity $\left(\mathrm{pD}_{2}\right)$ of the Mesenteric Artery of the SHR and WKY Rat. Raw Data.............58

21. Effect of STZ-induced Diabetes and of Food Restriction and Hypothyroidism on Responsiveness of the Mesenteric Artery of the SHR and WKY Rat. Raw Data................62 
INTRODUCTION

Essential hypertension is a disease of elevated blood pressure of no known cause characterized by an elevated total peripheral resistance (TPR) (Davidman and Opsah1, 1984). Many factors, including an increase in vascular reactivity and an altered vascular structure, have been proposed to be involved in the elevated TPR (Mulvany, 1983). The spontaneously hypertensive rat (SHR) is a widely used animal model for human essential hypertension. Elevated blood pressure in the SHR is, like human essential hypertension, characterized by an elevated TPR and a normal cardiac output (Smith and Hutchins, 1979).

Hypertension is one of many cardiovascular complications associated with diabetes mellitus and occurs in from 40 to 80 percent of diabetics (Christlieb, 1973). In contrast, diabetes in the SHR has a depressor effect, with the blood pressure of the SHR approaching that of normotensive controls (Somani et al, 1979; Cavaliere et al, 1980). In normotensive rats, the effect of STZ diabetes has been inconsistent with pressor and depressor effects reported (Somani et a1, 1979; Kohler et al, 1980; Jackson and Carrier, 1983). This difference in the effect on blood pressure of normotensive rats and SHR could be due in part to differences in the effects of STZ diabetes on the vasculature.

STZ diabetes could alter vascular structure by altering collagen synthesis and content. Resistance vessels in the SHR are characterized by medial hypertrophy and a reduced lumen, due to smooth muscle cell hypertrophy, hyperplasia and an increase in connective tissue components such as collagen (Mulvany et a1, 1978; Warshaw et a1, 1979; Olivetti et 
al, 1982). Collagen synthesis and content is increased in the aorta and mesenteric artery of the SHR (Ooshima et a1, 1974; Iwatsuki et a1, 1977; Ehrhart and Ferrario, 1981). In an aging study, Newman and Langner (1978) found these changes to occur only after the establishment of elevated blood pressure. STZ diabetes in normotensive rats decreases collagen synthesis in the aorta (Schneir et al, 1979). The effect of STZ diabetes in the SHR on vascular collagen synthesis and content is unknown.

STZ diabetes could also alter vascular reactivity to various vasoactive agents. Vascular reactivity is defined in terms of sensitivity and contractility. Sensitivity is inversely related to the agonist concentration required to produce half-maximal response. Contractility is related to the smooth muscle force generating capacity and is the maximum response which can be developed with a given agonist. The effects of diabetes on vascular reactivity of normotensive rats is influenced by the duration of diabetes. In general, aorta from STZdiabetic ( 4 to 12 week duration), normotensive rats are hyperresponsive to norepinephrine (NE) with no change in sensitivity (Owen and Carrier, 1979; Owen and Carrier, 1980; Scarborough and Carrier, 1983; Scarborough and Carrier, 1984b; MacLeod, 1985), hyposensitive and hyporesponsive to serotonin (5HT) (Owen and Carrier, 1979), and hyporesponsive to KCl (Pfaffman, 1980; Pfaffman et al, 1980; Pfaffman et al, 1982). Owen and Carrier (1979) also report a reduced but not significant decrease in response to KCL. Jackson and Carrier (1981) report no change in sensitivity or response to NE of the mesenteric artery from 4 week STZ diabetic normotensive rats. Diabetes of longer duration ( $\geq 3$ months) results in an increase in sensitivity and response to $\mathrm{NE}$ in the mesenteric artery of the normotensive rat (Jackson and Carrier, 1981; 
MacLeod, 1985).

In the nondiabetic SHR, there is a vessel-dependent response to vasoactive agents. Sensitivity of aorta from the SHR to $\mathrm{NE}$ and $\mathrm{KCl}$ is not different from that of normotensive rats (Shibata et al, 1973; Laher and Triggle, 1984). However, maximum response to $\mathrm{NE}, 5 \mathrm{HT}$, and $\mathrm{KCl}$ is reduced in aorta from SHR (Spector, 1969; Shibata, 1973). In contrast, the mesenteric artery from the SHR, in perfusion and isolated tissue studies, is supersensitive and hyperresponsive to the above agents (Haeusler and Haefely, 1970; Haeusler and Finch, 1972; Bhattacharya et al, 1977; Mulvany et al, 1980; Asano et al, 1984).

The effect of diabetes on the vascular reactivity of the SHR is unknown. The purpose of this study is to investigate whether a change either in vascular reactivity or in prolyl hydroxylase (PH) activity, which is a marker of collagen synthesis, are possible mechanisms for the hypotensive effect of STZ diabetes in the SHR. The working hypotheses of the study are as follows: 1) Diabetes depresses the reactivity of mesenteric arteries from SHR without affecting the reactivity of mesenteric arteries from WKY and 2) Diabetes reduces collagen synthesis in the aorta from SHR as indicated by a decrease in PH activity, but, does not affect $\mathrm{PH}$ activity of WKY aorta. It is assumed that a change in collagen synthesis will indicate an altered collagen metabolism in general. A reduction either in vascular reactivity or in collagen biosynthesis will suggest that STZ diabetes has a depressor effect in the SHR at least in part by interfering with vascular reactivity or collagen metabolism. 
METHODS

I. Animals. Male, age matched spontaneously hypertensive rats (SHR) and normotensive Wistar-Kyoto rats (WKY) were obtained from Charles River Laboratories Wilmington, Mass. The rats were housed collectively by strain and maintained on normal laboratory rat chow. The rats were fed and given water ad libitum.

II. Experimental Procedures

A. Induction of diabetes. Experimental diabetes was chemically induced by streptozotocin (STZ) (Sigma Chemical Company) in 14 to 16 week old rats. The rats received a single tail vein injection of STZ $(50 \mathrm{mg} / \mathrm{kg}$ ) dissolved in citrate buffer ( $\mathrm{pH} 4.5)$. Control rats were injected with the vehicle. The rats were diabetic for 8 - 9 weeks before sacrifice.

B. Induction of Hypothyroidism. Hypothyroidism was chemically induced by methimazole (Sigma Chemical Company) in 14 week old rats. Methimazole was added to the drinking water at a concentration of $0.01 \%$ $(10 \mathrm{mg} / 100 \mathrm{mls})$. The rats were maintained on methimazole for 8 - 9 weeks before sacrifice.

C. Protocol for Food Restriction. Rats, 14 to 16 weeks old, were placed on a food restricted diet. The rats were housed individually and given 1 - 2 pellets (10 grams) of rat chow per day. The rats were given water ad libitum. The rats were maintained on the food restricted diet for 8 - 9 weeks before sacrifice.

D. Blood Pressure and Metabolism Studies. Weekly blood pressure measurements and metabolism studies were determined for each rat. Blood 
pressure was measured by the indirect tail cuff method. Food intake, water intake, and urine production were measured by housing the rats individually in metabolism cages for 24 hours. Blood pressure and metabolism studies were performed on control and experimental rats before and during the appropriate treatment.

E. Isolation of Blood Vessels. Eight weeks after the induction of diabetes, or after the induction of hypothyroidism or food restriction, control and experimental rats were sacrificed by cervical dislocation. The heart was removed and the pooled blood in the chest cavity was collected and stored temporarily in a refrigerator. The mesenteric artery was isolated and a $2 \mathrm{~cm}$ piece was removed and placed in $100 \mathrm{ml}$ of oxygenated (958 $\mathrm{O}_{2}-58 \quad \mathrm{CO}_{2}$ ) Krebs-Henseliet buffer of the following composition (mM): $\mathrm{NaCl}$ (113), $\mathrm{KCL}$ (4.7), $\mathrm{CaCl}_{2}$ (2.5), $\mathrm{KH}_{2} \mathrm{PO}_{4}$ (1.2), $\mathrm{MgSO}_{4}$ (1.2), Glucose (11.5), $\mathrm{NaHCO}_{3}$ (19). The aorta was also removed, cleaned and rinsed in buffer, quick frozen in liquid nitrogen and stored at $-70^{\circ} \mathrm{C}$ until assayed for collagen.

Fat was carefully trimmed from the mesenteric artery so as to not stretch or damage the vessel. A 3 - $5 \mathrm{~mm}$ ring was cut and placed on two platinum hooks. Rings were used instead of helical strips because the former is relatively more intact, and more effectively measures the contraction of circular muscles which control vessel diameter (Moulds, 1983). The vessel was placed in a jacketed tissue chamber containing $100 \mathrm{ml}$ oxygenated $\mathrm{KH}$ buffer maintained at $37^{\circ} \mathrm{C}$. The bottom platinum hook was secured in the tissue chamber and the top hook was attached to a Grass FT03 force-displacement transducer. One gram of tension was placed on the vessel, and it was allowed to equilibrate for 90 minutes. The buffer was changed every thirty minutes throughout the experiment. 
F. Protocol for Agonist Addition. The vasoactive agents employed were norepinephrine (NE), 5-hydroxytryptamine (5HT), and methoxamine (MOX). Cocaine $\left(10^{-6} \mathrm{M}\right)$ was added to the buffer to prevent reuptake of norepinephrine (Webb and Vanhoutte, 1981). Developed tension responses were obtained over a range of $10^{-9} \mathrm{M}$ to $10^{-4} \mathrm{M}$ for $\mathrm{NE}$ and over a range of $10^{-7} \mathrm{M}$ to $10^{-4} \mathrm{M}$ for $5 \mathrm{HT}$ and methoxamine. The maximum response to a single addition of $100 \mathrm{mM} \mathrm{KCl}$ was also determined, in order to confirm tissue responsiveness. At the completion of each experiment, the tissues were lightly blotted and weighed.

G. Serum Analysis. The collected blood was centrifuged at $1400 \times \mathrm{g}$ for thirty minutes. The serum was separated and stored at $-70^{\circ} \mathrm{C}$ until analysis. The serum was analyzed for glucose, insulin and thyroxine $\left(\mathrm{T}_{4}\right)$. Glucose concentration was determined by Stanbio's OT-V Direct Glucose Test Kit. Insulin concentration was determined using Amersham's Radioimmunoassay (RIA) Kit. Intraassay variation was determined to be 11.38. T $T_{4}$ was measured using Amersham's $T_{4}$ RIA Kit. Intraassay variation was determined to be 9.18 .

H. Prolyl Hydroxylase Activity. The rate of collagen synthesis of the aorta was measured indirectly by prolyl hydroxylase activity. Prolyl hydroxylase activity was measured by the tritium release assay (Hutton et al, 1966). Aortas were homogenized in $1 \mathrm{ml}$ of $0.05 \mathrm{M}$ Tris $\mathrm{HCl}$ buffer ( $\mathrm{pH} 7.4$ ) containing $0.25 \mathrm{M}$ Sucrose, $10^{-5} \mathrm{M}$ EDTA, and $10^{-5} \mathrm{M}$ dithiothreitol, using a ground glass homogenizer. The homogenate was centrifuged at $15,000 \mathrm{~g}$ for 15 minutes and the supernatant was saved for PH assay. An aliquot $(200 \mu 1)$ of the homogenate was incubated with substrate and cofactors for 30 minutes at $30^{\circ} \mathrm{C}$. The reaction was stopped by addition of 100 ul 508 TCA. The titrated water was collected by distillation and counted. 
I. Data Presentation. Vascular reactivity was measured as sensitivity and as maximum response. Sensitivity of the tissue to each agonist was determined by calculation of $\mathrm{pD}_{2}$. The $\mathrm{pD}_{2}$ is defined as $-\log E D_{50}$. The $E D_{50}$ is the effective dose needed to produce $50 \%$ of the maximum response. The maximum response was defined as maximum tension developed (mg tension/mg wet tissue weight) at the maximally effective agonișt concentration (Mulvany, 1983).

J. Statistical Analysis. Where multiple means were present, the results were compared by a one-way ANOVA using an Apple II statistical computer program. Results with significant $F$ values were further analyzed for significance by a Newman-Keuls Test (Winer, 1971). Single comparisons of means were made using the unpaired Student's $t$ test. Significance was restricted to $\mathrm{p}<0.05$. 
RESULTS

I. General Observations. Metabolism cage measurements showed that the diabetic rats of both strains exhibited polyuria and polydipsia (Table I). Only WKY diabetic rats were polyphagic. The urine of the diabetic rat (either strain) exhibited a higher glucose content ( $>2000$ $\mathrm{mg} / \mathrm{dl}$ : Ames Diastix) than did the urine of control rats ( $<100 \mathrm{mg} / \mathrm{dl})$. The diabetic rats had apparently less skeletal muscle mass and fat deposits than did the controls.

II. Serum Analysis

A. Glucose concentration. Serum glucose levels were significantly elevated following induction of diabetes in the SHR and WKY (Table II). Food restriction and hypothyroidism had no effect on serum glucose levels in either strain.

B. Insulin Concentration. Diabetes significantly decreased serum insulin levels in the SHR and WKY (Table II). Food restriction and hypothyroidism significantly decreased serum insulin levels in the WKY only.

C. Serum $\mathrm{T}_{4}$ Concentration. STZ diabetes and food restriction produced hypothyroidism in both strains as indicated by lower $\mathrm{T}_{4}$ values (Table II). Hypothyroidism, induced by methimazole, significantly lowered $\mathrm{T}_{4}$ concentrations in both strains.

III. Blood Pressure Measurements. The SAP of nondiabetic SHR was elevated compared to that of the nondiabetic WKY group at all time points (Table III). The blood pressure of the diabetic SHR declined steadily relative to the nondiabetic SHR group becoming significant by 
the sixth week (Table III). Blood pressure of the diabetic WKY rats was not significantly different from blood pressure of the control WKY. Food restriction had no effect on blood pressure in either strain. Blood pressure of the hypothyroid zats was unobtainable by the tail cuff method.

IV. Prolyl Hydroxylase Activity. Diabetes significantly decreased prolyl hydroxylase activity in the aorta from the SHR when expressed per mg wet tissue weight and per mg protein (Table IV). PH activity per mg wet tissue weight in the aorta of the diabetic SHR decreased 87 per cent relative to the nondiabetic SHR. PH activity per mg protein in the aorta of the diabetic SHR decreased 70 percent when compared to the nondiabetic SHR. Only PH activity per mg wet tissue weight was significantly reduced in the diabetic WKY rat when compared to the nondiabetic WKY, with a decrease of 57 per cent. Food restriction and hypothyroidism had similar effects as diabetes on the $\mathrm{PH}$ activity in the aorta of the SHR and WKY rat (Tables IV, V). However, the decrease in $\mathrm{PH}$ activity due to food restriction and hypothyroidism in the SHR was only approximately 30 to 38 per cent when compared to the control SHR. The decrease in $\mathrm{PH}$ activity per mg wet tissue weight due to food restriction and hypothyroidism in the WKY was only approximately 26 to 38 per cent when compared to the control WKY.

V. Sensitivity of Mesenteric Artery. Diabetes and food restriction significantly increased the sensitivity of the mesenteric artery from both strains to MoX (Table VI). However, neither diabetes, food restriction nor hypothyroidism altered the sensitivity $\left(\mathrm{pD}_{2}\right)$ of the mesenteric artery from either strain to NE when compared to mesenteric arteries of the control rats of the same strain. Food restriction significantly increased the sensitivity of the mesenteric artery of both 
strains to 5HT. Hypothyroidism significantly decreased the sensitivity of the mesenteric artery of both strains to 5HT.

VI. Maximum Response of the Mesenteric Artery. Diabetes, hypothyroidism and food restriction had no effect on the maximum response of the mesenteric artery from the SHR to NE, 5HT, MOX, or KCL (Table VII). The maximum response of the mesenteric artery from the hypothyroid WKY rat to $5 \mathrm{HT}$ and $\mathrm{KCl}$ was significantly decreased. Diabetes, hypothyroidism and food restriction had no effect on the maximum response of the mesenteric artery from the WKY rat to NE and MOX. 
TABLE 1.--Effect of STZ-induced Diabetes ( 8 weeks) on Body Weight, Food Intake, Water Intake and Urine Output.

$\begin{array}{llcc}\text { Body } & \text { Food } & \text { Water } & \text { Urine } \\ \text { Weight } & \text { Intake } & \text { Intake } & \text { Output } \\ (\mathrm{g}) & (\mathrm{g} / 24 \mathrm{hr}) & (\mathrm{m} 1 \mathrm{~s} / 24 \mathrm{hr}) & (\mathrm{mls} / 24 \mathrm{hr})\end{array}$

SHR $\quad \mathrm{n}$

$\begin{array}{llllll}\text { Contro1 } & 10 & 325 \pm 15 & 23.1 \pm 2.2 & 23.0 \pm 13.4 & 9.5 \pm 4.4 \\ \text { Diabetic } & 8 & 194 \pm 41^{*} & 27.9 \pm 6.6 & 55.0 \pm 24.2^{*} & 40.0 \pm 23.3^{*}\end{array}$

WKY $\mathrm{n}$

Control $8 \quad 356 \pm 23 \quad 24.1 \pm 1.0 \quad 21.3 \pm 11.9 \quad 13.1 \pm 5.9$

Diabetic $7293 \pm 22^{*} \quad 41.6 \pm 3.4^{*} \quad 143.0 \pm 30.9^{*} \quad 122.9 \pm 25.0^{*}$

Note: Each value represents the mean \pm S.D.

* Denotes a significant difference when compared to age-matched control of the same strain $(p<0.05)$. 
TABLE 2.--Effect of STZ-induced Diabetes (8 weeks) and of Food Restriction and Hypothyroidism on Serum Glucose, Insulin and $\mathrm{T}_{4}$ of SHR and WKY Rats.

$\begin{array}{ccc}\text { Glucose } & \text { Insulin } & \mathrm{T}_{4} \\ \mathrm{mg} / \mathrm{dl} & \mu \mathrm{U} / \mathrm{ml} & \mu \mathrm{g} / \mathrm{d} 1\end{array}$

$\underline{\text { SHR }}$

$\mathrm{n}$

$\begin{array}{lrrrr}\text { Control } & 13 & 133 \pm 19 & 36.8 \pm 17.7 & 7.2 \pm 1.1 \\ \text { Diabetic } & 11 & 472 \pm 121^{*} & 19.5 \pm 6.5^{*} & 3.6 \pm 1.3^{*} \\ \text { Food Restricted } & 9 & 128 \pm 16 & 24.0 \pm 5.6 & 5.0 \pm 1.3^{*} \\ \text { Hypothyroid } & 7 & 143 \pm 25 & 30.2 \pm 13.4 & 2.2 \pm 0.3^{*}\end{array}$

$\underline{\text { WKY }}$

$\mathrm{n}$

Control $13 \quad 158 \pm 23 \quad 59.9 \pm 25.8 \quad 7.6 \pm 1.6$

Diabetic

10

$517 \pm 83^{*}$

$26.0 \pm 6.5^{*}$

$4.5 \pm 0.6^{*}$

Food Restricted 10

$167 \pm 56$

$24.0 \pm 6.4^{*}$

$5.6 \pm 0.9^{*}$

Hypothyroid

$7 \quad 150 \pm 27$

$34.6 \pm 13.5^{*}$

$2.5 \pm 0.2^{*}$

Note: Each value represents the mean \pm S.D.

* Denotes a significant difference when compared to age-matched control of the same strain $(p<0.05)$. 
TABLE 3.--Effect of STZ-induced Diabetes ( 8 weeks) and Food Restriction on Systolic Arterial Pressure (SAP) of SHR and WKY Rats.
Week: ${ }^{\mathrm{a}}$
0
2
4
6
8

$\underline{\text { SHR }}$

Control SAP (mm Hg) $179 \pm 20 \quad 185 \pm 19 \quad 185 \pm 19 \quad 200 \pm 21 \quad 206 \pm 26$

$\begin{array}{lllllll}\mathrm{n}= & 8 & 8 & 8 & 8 & 8\end{array}$

Diabetic SAP(m Hg) $175 \pm 29 \quad 184 \pm 37 \quad 171 \pm 37 \quad 165 \pm 24^{*} 152 \pm 33^{*}$

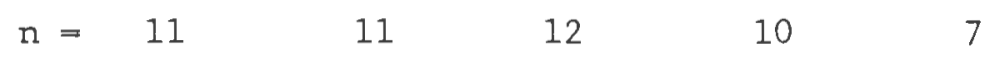

Food SAP (mm Hg) $189 \pm 28 \quad 183 \pm 18 \quad 207 \pm 18 \quad 204 \pm 20 \quad 203 \pm 20$

$\begin{array}{lllllll}\text { Restricted } & \mathrm{n}= & 10 & 10 & 9 & 10 & 8\end{array}$

WKY

Control SAP (mm Hg) $135 \pm 9 \quad 142 \pm 14 \quad 147 \pm 18 \quad 145 \pm 13 \quad 152 \pm 14$

$\begin{array}{llllll}\mathrm{n}= & 7 & 8 & 8 & 8 & 8\end{array}$

Diabetic SAP(mm Hg) $132 \pm 12 \quad 143 \pm 14 \quad 132 \pm 13 \quad 134 \pm 14 \quad 138 \pm 14$

$\begin{array}{llllll}\mathrm{n}= & 8 & 9 & 9 & 9 & 9\end{array}$

Food $\quad \operatorname{SAP}(\mathrm{mm} \mathrm{Hg}) \quad 147 \pm 18 \quad 152 \pm 12 \quad 153 \pm 21 \quad 162 \pm 20 \quad 156 \pm 18$

$\begin{array}{llllll}\text { Restricted } & \mathrm{n}= & 10 & 10 & 9 & 10\end{array}$

Note: Each value represents mean blood pressure \pm S.D.

a Designates number of weeks after STZ injection, start of methimazole or start of food restriction.

* Denotes a significant difference when compared to age-matched control of the same strain $(p<0.05)$. 
TABLE 4.--Effect of STZ-induced Diabetes ( 8 weeks) and Food Restriction on Prolyl Hydroxylase Activity in the Aorta of the SHR and WKY Rat.

$\begin{array}{cr}\mathrm{CPM} / \mathrm{mg} & \mathrm{CPM} / \mathrm{mg} \\ \text { wet weight } & \text { protein }\end{array}$

$\begin{array}{lccc}\text { SHR } & \text { n } & 149 \pm 11 & 4437 \pm 699 \\ \text { Control } & 5 & 19 \pm 11^{*} & 1340 \pm 583^{*} \\ \text { Diabetic } & 5 & 93 \pm 21^{*} & 3126 \pm 1220^{*} \\ \text { Food Restricted } & 5 & 90 \pm 12 & 3581 \pm 1128 \\ \text { WKY } & 4 & 39 \pm 6^{*} & 2319 \pm 404 \\ \text { Contro1 } & 4 & 67 \pm 11^{*} & 2965 \pm 1079 \\ \text { Diabetic } & 5 & & \\ \text { Food Restricted } & & & \\ \quad \text { Note: Each value represents the mean } \pm \text { S.D. } \\ \text { * Denotes a significant difference when compared to the age- } \\ \text { matched control of the same strain (p<0.05). }\end{array}$

TABLE 5.--Effect of Hypothyroidism on Prolyl Hydroxylase Activity in the Aorta of the SHR and WKY Rat.

$\begin{array}{cr}\mathrm{CPM} / \mathrm{mg} & \mathrm{CPM} / \mathrm{mg} \\ \text { wet weight } & \text { protein }\end{array}$

$\underline{\text { SHR }}$

$\begin{array}{lrrr}\text { Control } & 4 & 102 \pm 20 & 2914 \pm 167 \\ \text { Hypothyroid } & 7 & 64 \pm 8^{*} & 2028 \pm 298^{*}\end{array}$

WKY

$\begin{array}{llll}\text { Control } & 4 & 47 \pm 14 & 1966 \pm 703 \\ \text { Hypothyroid } & 7 & 29 \pm 11^{*} & 1239 \pm 482\end{array}$

Note: Each value represents the mean \pm S.D.

* Denotes a significant difference when compared to the agematched control of the same strain $(p<0.05)$. 
TABLE 6.--Effect of STZ-induced Diabetes (8 weeks) and of Food Restriction and Hypothyroidism on Sensitivity $\left(\mathrm{pD}_{2}\right)$ of the Mesenteric Artery of the SHR and WKY Rat.

$\begin{array}{ll} & \mathrm{pD}_{2} \\ \mathrm{NE} & \text { MHT }\end{array}$

$\underline{\text { SHR }}$

n

$\begin{array}{lccll}\text { Control } & 10 & 6.62 \pm 0.26 & 6.25 \pm 0.10^{* *} & 5.21 \pm 0.17^{* *} \\ \text { Diabetic } & 8 & 6.57 \pm 0.29 & 6.24 \pm 0.14 & 5.53 \pm 0.24^{*} \\ \text { Food Restricted } & 8 & 6.61 \pm 0.40 & 6.54 \pm 0.17^{*} & 5.48 \pm 0.21^{*} \\ \text { Hypothyroid } & 7 & 6.76 \pm 0.34 & 6.07 \pm 0.10^{*} & 5.08 \pm 0.11\end{array}$

WKY

n

Contro1

8

$6.66 \pm 0.36$

$5.97 \pm 0.09$

$4.98 \pm 0.19$

Diabetic

7

$6.53 \pm 0.26$

$6.07 \pm 0.05$

$5.39 \pm 0.12^{*}$

Food Restricted

7

$6.68 \pm 0.35$

$6.20 \pm 0.10^{*}$

$5.56 \pm 0.12^{*}$

Hypothyroid

$7 \quad 6.42 \pm 0.09$

$5.77 \pm 0.12^{*}$

$4.87 \pm 0.16$

Note: Each value represents the mean \pm S.D.

* Denotes a significant difference when compared with age-matched control rats of the same strain $(p<0.05)$.

** Denotes a significant difference when compared with age-matched WKY control rats $(p<0.05)$. 
TABLE 7.--Effect of STZ-induced Diabetes ( 8 weeks) and of Food Restriction and Hypothyroidism on Responsiveness of the Mesenteric Artery of the SHR and WKY Rat. Maximum change in tension ( $\mathrm{mg} / \mathrm{mgwet} \mathrm{wt}$ )

$\begin{array}{cccc}\mathrm{NE} & 5 \mathrm{HT} & \text { MOX } & \text { KC1 } \\ \left(10^{-4} \mathrm{M}\right) & \left(10^{-4} \mathrm{M}\right) & \left(10^{-4} \mathrm{M}\right) & (100 \mathrm{mM})\end{array}$

$\underline{\mathrm{SHR}}$

$\mathrm{n}$

Control $\quad 10 \quad 868 \pm 372^{* *} \quad 1057 \pm 384 \quad 926 \pm 402 \quad 566 \pm 258$

$\begin{array}{llllll}\text { Diabetic } & 8 & 1267 \pm 395 & 1309 \pm 587 & 1267 \pm 527 & 681 \pm 246\end{array}$

Food Restricted $8 \quad 1027 \pm 144 \quad 1308 \pm 262 \quad 1237 \pm 402 \quad 711 \pm 282$

$\begin{array}{llllll}\text { Hypothyroid } & 7 & 930 \pm 267 & 1022 \pm 305 & 930 \pm 320 & 589 \pm 129\end{array}$

WKY $\quad \mathrm{n}$

Control $\quad 8 \quad 1405 \pm 499 \quad 1389 \pm 592 \quad 1392 \pm 697 \quad 740 \pm 439$

$\begin{array}{llllll}\text { Diabetic } & 7 & 1512 \pm 601 & 1566 \pm 678 & 1698 \pm 748 & 876 \pm 434\end{array}$

Food Restricted $7 \quad 1331 \pm 416 \quad 1503 \pm 537 \quad 1598 \pm 471 \quad 791 \pm 222$

Hypothyroid $\quad 71201 \pm 512 \quad 770 \pm 322^{*} \quad 783 \pm 225 \quad 324 \pm 118^{*}$

Note: Each value represents the mean \pm S.D.

* Denotes a significant difference when compared with age-matched control rats of the same strain $(p<0.05)$.

** Denotes a significant difference when compared with age-matched WKY control rats $(p<0.05)$. 


\section{DISCUSSION}

The spontaneously hypertensive rat (SHR), an animal model for human essential hypertension, exhibits an elevated blood pressure characterized by an increased total peripheral resistance (TPR) (Smith and Hutchins, 1979). This increased TPR implies differences in the vasculature of the SHR compared to normotensive rats. Changes could include structural, functional and membrane differences.

Essential hypertension is a complication of diabetes mellitus (Christlieb, 1973). However, experimental diabetes, induced by either STZ or alloxan, in the SHR has a depressor effect (Table III; Somani et a1, 1979; Cavaliere et al, 1980). In contrast, STZ diabetes in the WKY strain had no effect on SAP (Table III). In the present study STZ diabetic SHR were hypotensive, relative to the nondiabetic SHR group by the sixth week after the injection of STZ. The depressor effect might be associated with diabetes-induced alterations in vascular reactivity or collagen biosynthesis.

Structurally, resistance vessels in the SHR are characterized by medial hypertrophy and a reduced lumen, due to smooth muscle cell hypertrophy, hyperplasia, and an increase in connective tissue components such as collagen (Mulvany et al, 1978; Warshaw et al, 1979; Olivetti et a1, 1982). It appears that structural changes are a consequence and not a cause of the elevated pressure. Mulvany et al (1980) found no medial hypertrophy in prehypertensive SHR (6 weeks) but did observe medial hypertrophy in hypertensive SHR (12 and 24 weeks). Prehypertensive SHR, treated with captopril, remained normotensive and did not exhibit medial hypertrophy when compared to WKY (Henrich et al, 1980). Little is known 
about the effect of STZ diabetes on the smooth muscle cell. In the aorta, no histological differences or difference in wall thickness were observed for control, STZ diabetic and insulin-treated diabetic normotensive rats (Pfaffman et al, 1982).

Other structural components such as connective tissue (collagen) are increased in the aorta and mesenteric artery of the SHR (Ooshima et a1, 1974; Iwatsuki et al, 1977). Connective tissue is essential to the strength, structure, and integrity of tissues. Procollagen is the precursor of collagen consisting of three polypeptide chains in a triple helix. The chains have a high content of glycine, proline, hydroxyproline and lysine (Gilligan and Spector, 1984). The triple helix is stabilized by the hydroxylation of specific prolines by the action of prolyl hydroxylase (Hutton et a1, 1966). The reaction involves a direct displacement of the hydrogen atom on carbon four with the released hydrogen equilibrating with water. Carboxyprotease and lysyl oxidase are then involved in the conversion of procollagen into collagen and collagen into fibrils by crosslinking through lysyl or hydroxylysyl amino acids, respectively.

STZ diabetes decreases collagen biosynthesis, as indicated by a decrease in PH activity (Table IV) in the SHR and WKY. This agrees with a previous study in the normotensive rat (Schneir et al, 1979). The results suggests that alteration of collagen synthesis by STZ diabetes could be responsible for the depressor effect in the SHR. However, during the genesis of hypertension in the SHR, increases in collagen synthesis and content occurs only after the establishment of elevated blood pressure (Newman and Langner, 1978). Whether the observed decrease in collagen synthesis in the STZ diabetic SHR occurs before or after the drop in blood pressure is open to speculation. Caloric 
deprivation and hypothyroidism also decrease $\mathrm{PH}$ activity in the SHR and WKY, but, neither can fully explain the effect of STZ diabetes (Table IV, V).

The above structural changes in the nondiabetic SHR appear to be adaptive changes to the elevated blood pressure. Therefore, some other mechanisms must be involved in the elevation of blood pressure in the SHR. Vascular smooth muscle function has been extensively investigated as a possible mechanism and is altered in the SHR when compared to normotensive rats. One such altered function is the vascular reactivity to various vasoactive agents. The mesenteric artery from the SHR, in perfusion and isolated tissue studies, is supersensitive and hyperresponsive to $\mathrm{NE}$, 5HT, and $\mathrm{KCl}$ (Haeusler and Haefely, 1970; Haeusler and Finch, 1972; Bhattacharya et al, 1977; Mulvany et al, 1980; Asano et al, 1984). Results showing increased sensitivity to $\mathrm{NE}$ in prehypertensive SHR suggest that the altered vascular reactivity occurs prior to the development of elevated blood pressure (Lais and Brody, 1978; Mulvany et a1, 1980).

Evidence indicates that the altered vascular reactivity in the SHR may be related to a vascular membrane abnormality. Calcium sensitivity of vessels from SHR is increased (Mulvany and Nyborg, 1980; Nilsson and Mulvany, 1981). In isolated tissue studies, as calcium concentration is increased, the maximum response of mesenteric vessels from prehypertensive and hypertensive SHR to a fixed concentration of $\mathrm{NE}$ is increased. Mulvany and Nyborg (1980) observed no difference in calcium sensitivity to a $\mathrm{KCl}$ response. $\mathrm{NE}$ and $\mathrm{KCL}$ interact with different calcium channels and the results indicate that the $\mathrm{NE}$ activated calcium channels in the SHR are different from those of the WKY (Nilsson and Mulvany, 1981). The observed calcium sensitivity is also found in the visceral smooth 
muscle of the SHR (Altman et al, 1977) and in the mesenteric artery of denervated SHR (Mulvany et al, 1981). Therefore, the increase in calcium sensitivity of SHR smooth muscle is not restricted to the vasculature and thus is probably not a consequence of increased blood pressure or neurogenically mediated.

Other calcium properties of vascular smooth muscle appear to be altered in the SHR. Calcium binding has a stabilizing effect on the membrane and inhibits contraction. Calcium binding of the mesenteric artery of the SHR has been reported to be decreased (Webb and Bohr, 1981) or the same as normotensive rats (Kwan and Daniel, 1981). If vessels of the SHR do have a decrease in calcium binding, then the membranes may be less stable making them more susceptible to contraction. An ATP-dependent calcium transport has been identified in rat mesenteric arteries (Daniel et al, 1982) and is altered in the SHR. ATP-dependent calcium accumulation is decreased in mesenteric arteries of young and adult SHR (Kwan et al, 1979; Kwan, 1985).

Permeability of other ions such as $\mathrm{Na}^{+}$and $\mathrm{K}^{+}$of vascular smooth muscle of SHR is also increased (Jones, 1973). Increased passive movement of $\mathrm{Na}^{+}$and $\mathrm{K}^{+}$should lead to a less negative membrane potential, but membrane potential in the SHR is similar to normotensive rats. Hermsmeyer et al (1976) observed that the electrogenic $\mathrm{Na}^{+}-\mathrm{K}^{+}$pump activity is increased in the SHR to offset the increased passive permeability. They also proposed that the greater response to NE in the SHR is the result of this increased $\mathrm{Na}^{+}-\mathrm{K}^{+}$pump activity.

In the present study, alpha-adrenoreceptor reactivity of the nondiabetic SHR is altered compared to the nondiabetic WKY. The sensitivity of the mesenteric artery to $\mathrm{NE}$ is not altered in the nondiabetic SHR, while the responsiveness is significantly reduced when 
compared to the nondiabetic WKY (Table VI, VII). Alpha-adrenoreceptors, pharmacologically classified as $\alpha_{1}$ and $\alpha_{2}$ (Bethelsen and Pettinger, 1977; Godfraind et al, 1982), have been located in the rat mesenteric artery (Agrawal et al, 1984). Radioligand binding studies indicate that the $\alpha_{1}$ subtype is predominant in this tissue (Colucci et al, 1980). The increase in sensitivity to MOX, an $\alpha_{1}$ agonist, and the absence of any change in sensitivity to $N E$, a nonselective $\alpha_{1}$ and $\alpha_{2}$ agonist suggests a change in the affinity of the $\alpha_{1}$-receptors for Mox, even though direct evidence is not available (Table VI). The results of the reactivity to NE disagree with the previous observations (Bhattacharya et al, 1977; Mulvany et al, 1980; Asano et al, 1984). Since there is an increase in the sympathetic nerve activity in the SHR (Judy et al, 1979), the decrease in postjunctional reactivity to NE could be the result of a compensatory mechanism. An increase in sympathetic nervous system tone might be expected to result in down regulation of alpha-adrenoreceptors. This seems unlikely since the above studies did not see this. The difference between this study and the above studies may simply be due to the method of tissue preparation. The above studies used either a mesenteric bed preparation or a helical strip of the mesenteric artery. A mesenteric bed preparation involves a mixture of vessel types. If a difference in responsiveness is observed, its impossible to tell which vessel type is contributing to the observed difference in responsiveness. Helical strips destroy the integrity of the vessel and are not as physiologically representative as rings (Moulds, 1983). In this study, using an isolated artery ring, the mesenteric artery of the nondiabetic SHR has a similar reactivity to $N E$ as previously reported for the aorta (Spector, 1969; Shibata et al, 1973; Laher and Iriggle, 1984).

It appears that diabetes may alter $\alpha$-adrenoreceptor response in 
the SHR. Maximum response to NE and MOX is increased, although not significantly, in the diabetic SHR as compared to the nondiabetic SHR (Table VII). This increase not being significant may be due to the high variability observed. The increased response to NE and MOX suggests an altered $\alpha_{1}$-activity in the mesenteric artery of the diabetic SHR. Activity may be altered by a change in the binding properties or number of $\alpha_{1}$-adrenoreceptors or in the sequence of events leading to contraction after receptor activation. A lack of change in $\mathrm{NE}$ sensitivity ( $\mathrm{pD} 2$, Table VI) in the diabetic SHR (vs nondiabetic SHR) suggests that $\alpha_{1}$ adrenoreceptor number is not altered. Therefore, the altered NE response is the result of a change in the events after receptor activation. Recent observations indicate that a membrane abnormality may be involved. Both $\alpha_{1}$ and $\alpha_{2}$ induced contractions are biphasic and involve intracellular and extracellular calcium (Scarborough and Carrier, 1984a). Diabetes increases the sensitivity of the aorta to calcium and increases the influx of extracellular calcium due to $\alpha_{2}$ activation in the aorta of normotensive rats (Owen and Carrier, 1980; Scarborough and Carrier, 1984b). Even though no direct evidence is available, Jackson and Carrier (1981) proposed that the increase in responsiveness in the mesenteric artery of STZ diabetic normotensive rat may be due to an increase in calcium utilization by the smooth muscle cell of the mesenteric artery. If calcium influx due to $\alpha_{1}$ activation and calcium utilization is increased in the diabetic SHR, one would expect an increase in the maximum response to $\mathrm{NE}$ and $\mathrm{MOX}$ in the diabetic SHR. The increase in response to NE and MOX, even though not significant, in the mesenteric artery of the diabetic SHR indicates that an increase in calcium influx and calcium utilization may be occurring.

Diabetes increases the sensitivity of the mesenteric artery of the 
SHR to MOX (Table VI) suggesting a change in affinity of the $\alpha_{1}$ receptors for MOX even though no direct evidence is presented. Therefore, in regards to MOX, the increase in maximum response to MOX in the diabetic SHR may be the result of an increase in affinity and a change in the events after $\alpha_{1}$ receptor activation, such that the response to MOX is similar to the response to $\mathrm{NE}$.

Diabetes does not alter NE sensitivity or response of the mesenteric artery of the WKY (Table VI, VII), supporting recent observations in short term diabetes (Jackson and Carrier, 1981). In the same study, Jackson and Carrier observed mesenteric arteries from long term diabetic rats to be supersensitive and hyperresponsive to NE. Therefore, it appears that the sensitivity and response of the mesenteric artery from diabetic normotensive rats to $N E$ is dependent upon the duration of diabetes. The sensitivity of the mesenteric artery of the diabetic WKY to MOX is similar to that of the diabetic SHR (Table VI), suggesting a change in affinity of $\alpha_{1}$ receptors for MOX.

The mesenteric artery of the nondiabetic SHR is supersensitive to 5HT supporting previous results (Table VI; Haeusler and Finch, 1972). No change in response to $\mathrm{KCl}$ was present, in contrast to earlier studies (Table VII; Haeusler and Finch, 1972; Asano et al, 1984). Diabetes has no effect on the sensitivity or response of the mesenteric artery of either strain to $5 \mathrm{HT}$ and $\mathrm{KCI}$ (Table VI, VII).

The contributory effect of a reduction in thyroid hormones on the increase in response of the mesenteric artery of the diabetic SHR to NE was investigated. The results indicate that hypothyroidism did not alter the sensitivity or responsiveness of the mesenteric artery of either strain to NE, supporting a recent study (Table VI, VII; Ishac and Pennefather, 1983). Therefore, it appears that a reduction in thyroid hor- 
mones is not a factor in the observed increase in response in the diabetic SHR.

Hypothyroidism alters the sensitivity of the mesenteric artery of both strains to $5 \mathrm{HT}$ (Table VI). In the WKY, the decrease in sensitivity was accompanied by a decrease in response (Table VII). In the WKY, a decrease in response to $\mathrm{KCl}$ was also observed. $\mathrm{KCl}$ contractions involve the influx of calcium through voltage dependent channels (Mulvany and Nyborg, 1980). Whether the observed decrease is the result of hypothyroidism affecting the influx of calcium through these channels is unknown.

Since STZ-induced diabetes is accompanied by an altered nutritional state (Madia et al, 1979) and caloric restriction reduced blood pressure in the SHR (Young et al, 1978), a food restricted control was included. Food restriction increased the sensitivity of the mesenteric artery of both strains to $5 \mathrm{HT}$ and MOX, but had no effect on responsiveness (Table VI, VII). Since the sensitivity to MOX was increased in both the diabetic and food restricted rats, the effect of diabetes on sensitivity to Mox may be related in part to the altered nutritional state rather than to the lack of insulin or the hypoglycemia. Food restriction did not affect the sensitivity or responsiveness of the mesenteric artery of either strain to NE or $\mathrm{KCl}$, which agrees with a recent study using normotensive rats (Longhurst and Head, 1985).

Other systems which regulate blood pressure include the sympathetic nervous system and the renal system. The role of each in hypertension in unknown. Judy et al (1979) observed an increase in sympathetic nerve activity (SNA) in young and adult SHR. By crossbreeding SHR and WKY to produce a range of blood pressures, SNA decreased in direct proportion to the decrease in blood pressure. This suggests that 
the sympathetic nervous system plays a major role in the development and management of hypertension in the SHR. Sympathetic denervation by pithing reduced blood pressure in the sHR to normotensive levels (Albrecht et al, 1975). Arterial pressure is a combination of peripheral resistance and cardiac output. When Albrecht et al measured peripheral resistance they found it to still be increased in the pithed SHR. Equal blood pressure in the pithed SHR was the result of an equal decrease in cardiac output. Denervation by immunosympathectomy in newborn SHR produced a reduced (vS SHR controls) but still higher (vs denervated normotensives) blood pressure (Folkow et al, 1972). These results suggest that an increased SNA may be partially involved in the initiation and maintenance of the increased blood pressure in the SHR. The role of the sympathetic nervous system in diabetes is unknown. Abnormalities of the peripheral nerves, characterized by a decrease in conduction velocity, has been demonstrated in the STZ diabetic normotensive rat (Thomas et al, 1981). Whether this diabetic neuropathy occurs in the STZ diabetic SHR is unknown. If it does occur, it may produce an effect similar to that of sympathetic denervation and may be a. contributory factor in the depressor effect of STZ in the SHR.

Altered renal function may also be involved in the initiation and maintenance of elevated blood pressure in the SHR. Renal blood flow and glomerular filtration appear to be normal indicating an elevated renal vascular resistance (Arendshorst and Beierwaltes, 1979). The elevated renal vascular resistance is the result of both an increase in sympathetic nerve activity and a structural abnormality (Arendshorst and Beierwaltes, 1979; Collis and Vanhoutte, 1977). The kidney also produces pressor substances which circulate in the blood. Inconsistent results on plasma renin activity in the SHR have been reported (Sen et 
al, 1972; Forman and Mulrow, 1974; Bagby et al, 1979). Renin is involved in the formation of angiotensin II and captopril, which inhibits this formation of angiotensin II, lowers blood pressure in the SHR (Koike et al, 1980). These results indicate that circulating pressor substances may play a role in the elevated blood pressure in the SHR. STZ diabetes produces early renal changes characterized by an increase in. glomerular basement membrane, glomerular filtration rate and plasma renin activity (Carney et al, 1979; Kohler et al, 1980). These changes indicate that diabetes may increase blood pressure. Therefore, it seems unlikely that renal changes are playing a role in the depressor effect of STZ in the SHR. 


\section{SUMMARY}

1. STZ-induced diabetes has a depressor effect in the SHR. Blood pressure in the WKY is not affected by STZ-induced diabetes. These results suggest differences in the vasculature of the two strains.

2. STz-induced diabetes alters collagen biosynthesis, as indicated by a decrease in $\mathrm{PH}$ activity, of both strains. The effect is greater in the SHR suggesting that the depressor effect of STZ-induced diabetes may be related to a reduction in collagen synthesis. Food restriction and hypothyroidism also reduced PH activity, but to a lesser extent than did STZ-induced diabetes suggesting that the decrease in collagen biosynthesis in diabetes may be explained in part by the altered nutritional status and the reduction in thyroid hormones associated with diabetes. 3. STZ-induced diabetes increases, though not significantly, the response of the mesenteric artery of the SHR to NE and MOX suggesting an altered $\alpha_{1}$-adrenoreceptor response. Since no change in sensitivity to NE was observed, the results suggests that STZ-induced diabetes alters the series of events after receptor activation that lead to contraction. STZ-induced diabetes alters calcium influx due to $\alpha_{2}$ activation in the aorta of normotensive rats. Whether the same effect is occurring in the SHR, with respect to $\alpha_{1}$ activation is unknown.

4. The above effects of diabetes on arterial reactivity are not well correlated with the depressor effect of STZ in the SHR. The effects of STZ-induced diabetes on arterial response to adrenoreceptor agonists in the SHR might be expected to produce a pressor response, not the observed depressor response. Therefore, it appears that the depressor effect of STZ in the SHR is not related to the altered vascular reactivity. 
BIOLOGICAL RELEVANCE

1. The initial intent of this research project was to develop a diabetic, hypertensive animal model. Since STZ-induced diabetes reduced blood pressure in the SHR, the original intent was not accomplished. Other diabetic animals and other hypertensive animal models and combinations thereof need to be investigated.

2. A decrease in collagen biosynthesis, as indicated by a decrease in $\mathrm{PH}$ activity, was well correlated with the decrease in blood pressure in the diabetic SHR. The results indicate that reducing collagen biosynthesis and content may be an effective treatment of hypertension. It may be possible to treat hypertension clinically with drugs that reduce collagen biosynthesis and content. At present, some antihypertensives have been shown to reduce blood pressure and collagen biosynthesis and content in rats (Gilligan and Spector, 1984). 
APPENDIX

$\begin{array}{lcc}\text { TABLE 8.--Prolyl Hydroxylase Distillation Recovery. } & \\ \text { Sample } & \text { CPM } & \text { \& Recovery } \\ \text { Blank } & 20.3 & - \\ \text { Undistilled } & 223.1 & - \\ \text { First Replicate } & 215.6 & 96.6^{\mathrm{b}} \\ \text { Second Replicate } & 208.5 & 93.5^{\mathrm{b}} \\ \text { Third Replicate } & 221.6 & 99.3^{\mathrm{b}} \\ & & X=96.5 \pm 2.9\end{array}$

a Prolyl hydroxylase distillation step was carried out using a reaction mix spiked with tritiated water. Results indicate good recovery and excellent repeatability. Recovery values validate that the assay is working in my hands.

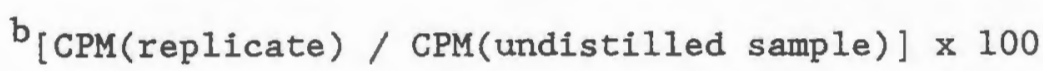


TABLE 9.--Lowry Protein Assay. Test for Interference of Tissue Homogenate.

$\begin{array}{ccccc}\begin{array}{c}\text { Standard } \\ \mu \mathrm{g} \mathrm{BSA} / 100 \mu \mathrm{As}(750 \mathrm{~nm})^{\mathrm{a}}\end{array} & \begin{array}{c}\text { Expected } \\ 5\end{array} & \text { Abs }(750 \mathrm{~nm})^{\mathrm{b}} & \text { Abs }(750 \mathrm{~nm})^{\mathrm{c}} & \text { \& Difference } \\ 10 & 0.065 & 0.407 & 0.349 & -14 \\ 20 & 0.111 & 0.453 & 0.435 & -4 \\ 30 & 0.201 & 0.543 & 0.516 & -5 \\ 40 & 0.313 & 0.655 & 0.629 & -4 \\ 50 & 0.448 & 0.790 & 0.750 & -5 \\ & 0.549 & 0.891 & 0.880 & -1\end{array}$

Tissue

Homogenate $\quad 0.342$

$(20 \mu 1$ aliquot)

a Observed absorbance of standards and tissue homogenate sample.

b Expected absorbance value = observed absorbance +0.342 i.e. for the $5 \mu 1$ standard expected Abs of $0.407=0.065+0.342$.

c Actual absorbance observed for standards spiked with $20 \mu 1$ of tissue homogenate.

d o difference between actual absorbance and expected absorbance. These results indicate that the reaction mixture has negligible effect on the assay, therefore, the Lowry assay is valid under my sample conditions. 
TABLE 10.-Effect of STZ-induced Diabetes on Body Weight of the SHR and WKY Rat. Raw Data.

$\begin{array}{cccc}\underline{\text { SHR }} & \text { Body Weight } & \text { SHR } & \text { Body } \\ \text { Control } & \text { Dight } & \\ 1 & 303 & (\mathrm{~g}) \\ 2 & 325 & 2 & 211 \\ 3 & 346 & 3 & 261 \\ 4 & 311 & 4 & 169 \\ 5 & 334 & 5 & 174 \\ 6 & 335 & 6 & 164 \\ 7 & 315 & 7 & 247 \\ 8 & 344 & 8 & 158 \\ 9 & 324 & & 167 \\ 10 & 313 & & \end{array}$

$\begin{array}{lccc}\text { WKY } & \text { Body Weight }{ }^{\mathrm{a}}(\mathrm{g}) & \text { WKY } & \text { Body Weight }^{\mathrm{a}} \text { (g) } \\ \text { Control } & & \text { Diabetic } & \\ 1 & 368 & 1 & 316 \\ 2 & 333 & 2 & 262 \\ 3 & 362 & 3 & 266 \\ 4 & 330 & 4 & 319 \\ 5 & 326 & 5 & 293 \\ 6 & 361 & 6 & 304 \\ 7 & 389 & 7 & 291 \\ 8 & 375 & & \end{array}$


TABLE 11.-Effect of STZ-induced Diabetes on the Food Consumption of the SHR and WKY Rat. Raw Data.

\begin{tabular}{cccc} 
SHR & Food & \multicolumn{1}{l}{ SHR } & Food Intake $^{a}(\mathrm{~g} / 24 \mathrm{hr})$ \\
Control & 23 & Diabetic & \\
1 & 24 & 1 & 35 \\
2 & 22 & 2 & 30 \\
3 & 20 & -3 & 23 \\
4 & 26 & 4 & 22 \\
5 & 27 & 5 & 26 \\
6 & 22 & 6 & 40 \\
7 & 21 & 7 & 24 \\
8 & 22 & 8 & 23 \\
9 & 24 & & \\
10 & & &
\end{tabular}

$\begin{array}{lccc}\text { WKY } & \text { Food Intake }{ }^{\mathrm{a}}(\mathrm{g} / 24 \mathrm{hr}) & \text { WKY } & \text { Food Intake }(\mathrm{g} / 24 \mathrm{hr}) \\ \text { Control } & & \text { Diabetic } & \\ 1 & 25 & 1 & 39 \\ 2 & 24 & 2 & 40 \\ 3 & 24 & 3 & 39 \\ 4 & 22 & 4 & 42 \\ 5 & 25 & 5 & 44 \\ 6 & 24 & 6 & 39 \\ 7 & 25 & 7 & \\ 8 & 24 & \end{array}$


TABLE 12.--Effect of STZ-induced Diabetes on the Water Consumption of the SHR and WKY Rat. Raw Data.

$\begin{array}{cccc}\text { SHR } & \text { Water Intake }(\mathrm{mls} / 24 \mathrm{hr}) & \underline{\text { SHR }} & \text { Water Intake }{ }^{\mathrm{a}}(\mathrm{mls} / 24 \mathrm{hr}) \\ \text { Control } & 35 & \text { Diabetic } & \\ 1 & 15 & 2 & 70 \\ 2 & 35 & 3 & 60 \\ 3 & 40 & 4 & 45 \\ 4 & 40 & 5 & 30 \\ 5 & 20 & 6 & 105 \\ 6 & 20 & 7 & 35 \\ 7 & 10 & 8 & 55 \\ 8 & 5 & & \\ 9 & 10 & & \\ 10 & 50 & & \end{array}$

\begin{tabular}{|c|c|c|c|c|}
\hline WKY & Water Intake ${ }^{a}(\mathrm{mls} / 24 \mathrm{hr})$ & $\underline{\text { WKY }}$ & Water & Intake ${ }^{a}(\mathrm{~m} 1 \mathrm{~s} / 24 \mathrm{hr})$ \\
\hline Control & & Diabetic & & \\
\hline 1 & 15 & 1 & & 140 \\
\hline 2 & 30 & 2 & & 110 \\
\hline 3 & 25 & 3 & & 125 \\
\hline 4 & 20 & 4 & & 155 \\
\hline 5 & 45 & 5 & & 200 \\
\hline 6 & 10 & 6 & & 155 \\
\hline 7 & 10 & 7 & & 115 \\
\hline 8 & 75 & & & \\
\hline
\end{tabular}

${ }^{a}$ Rats were housed individually in metabolism cages and given 600 $\mathrm{mls}$ of water. After $24 \mathrm{hrs}$ the rats were removed from the cages and the water consumption was recorded. Values reported are the last measurements before sacrifice. 
TABLE 13.--Effect of STZ-induced Diabetes on the Urine Production of the SHR and WKY Rat. Raw Data.

\begin{tabular}{|c|c|c|c|c|}
\hline$\underline{\text { SHR }}$ & Urine & Output $^{\mathrm{a}}$ (m1s/24hr) & $\underline{\mathrm{SHR}}$ & Urine output ${ }^{a}$ \\
\hline Control & & & Diabetic & \\
\hline 1 & & 10 & 1 & 40 \\
\hline 2 & & 10 & 2 & 40 \\
\hline 3 & & 10 & 3 & 20 \\
\hline 4 & & 10 & 4 & 20 \\
\hline 5 & & 5 & 5 & 20 \\
\hline 6 & & 5 & 6 & 90 \\
\hline 7 & & 5 & 7 & 40 \\
\hline 8 & & 10 & 8 & 50 \\
\hline 9 & & 10 & & \\
\hline 10 & & 20 & & \\
\hline
\end{tabular}

$\begin{array}{cccc}\text { WKY } & \text { Urine } \text { Output }^{\mathrm{a}}(\mathrm{mls} / 24 \mathrm{hr}) & \frac{\text { WKY }}{\text { Urine Output }}{ }^{\mathrm{a}} \text { (mls/24hr) } \\ \text { Control } & & \text { Diabetic } & \\ 1 & 5 & 1 & 120 \\ 2 & 10 & 2 & 90 \\ 3 & 10 & 3 & 110 \\ 4 & 10 & 4 & 140 \\ 5 & 20 & 5 & 160 \\ 6 & 10 & 6 & 140 \\ 7 & 20 & 7 & 100 \\ 8 & 20 & & \end{array}$

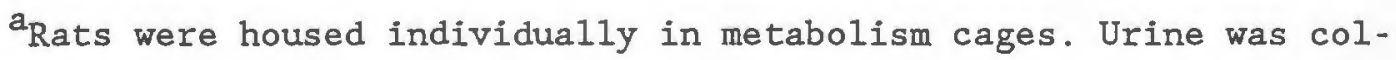
lected for $24 \mathrm{hrs}$ and the amount recorded. Values reported are the last measurements before sacrifice. 
TABLE 14.--Effect of STZ-induced Diabetes and of Food Restriction and Hypothyroidism on Serum Glucose of the SHR and WKY Rat. Raw Data.

$\begin{array}{cc}\text { Standards (mg/dl) } & \text { Absorbance } \\ 50 & 0.041 \\ 100 & 0.078 \\ 200 & 0.172 \\ 300 & 0.237 \\ 400 & 0.327 \\ 500 & 0.421\end{array}$

$\begin{array}{cccc}\text { Absorbance } & \text { Glucose } & \text { Absorbance } & \text { Glucose }^{a} \\ \text { a 500nm } & \mathrm{mg} / \mathrm{dl} & \text { a } 500 \mathrm{~nm} & \mathrm{mg} / \mathrm{d} 1\end{array}$

$\underline{\text { SHR }}$

Control

1

2

3

4

5

6

7

8

9

10

11

12

13
0.121

0.075

0.110

0.128

0.144

0.111

0.108

0.111

0.098

0.108

0.104

0.117

0.103 $\underline{\text { SHR }}$

Diabetic ${ }^{b}$

145

90

132

154

173

133

130

133

118

130

125

140

124
$0.073 \quad 438$

$0.045 \quad 270$

$0.059 \quad 354$

$0.068 \quad 408$

$0.078 \quad 468$

$0.078 \quad 468$

$0.079 \quad 474$

$0.121 \quad 726$

$0.102 \quad 612$

$0.087 \quad 522$

$0.075 \quad 450$ 
TABLE 14 Continued

Food Restricted

$\begin{array}{lll}1 & 0.119 & 143 \\ 2 & 0.105 & 126 \\ 3 & 0.120 & 144 \\ 4 & 0.109 & 131 \\ 5 & 0.085 & 102 \\ 6 & 0.083 & 100 \\ 7 & 0.109 & 131 \\ 8 & 0.116 & 139 \\ 9 & 0.111 & 133\end{array}$

WKY

Contro1

1

2

3

4

5

6

7

8

9

10

11

12

13
0.143

0.145

0.115

0.122

0.142

0.123

0.138

0.121

0.105

0.118

0.172

172

174

138

146

170

148

166

145

126

142

206

187

140
Hypothyroid

$\begin{array}{lll}1 & 0.123 & 148 \\ 2 & 0.107 & 128 \\ 3 & 0.093 & 112 \\ 4 & 0.106 & 127 \\ 5 & 0.110 & 132 \\ 6 & 0.138 & 166 \\ 7 & 0.154 & 185\end{array}$

WKY

Diabetic ${ }^{b}$

1

0.078

468

2

0.083

498

0.068

408

$0.086 \quad 516$

$0.094 \quad 564$

6

0.096

576

7

0.115

690

8

0.075

450

9

0.074

444

10

0.092

552 
TABLE 14 Continued

Food Restricted

1

2

3

4

5

6

7

8

9

10
0.094

0.083

0.141

0.133

0.182

0.177

0.185

0.124

0.070

0.201

Glucose of rat serum determined by using Stanbio's OT-V Direct
Hypothyroid

113

1

0.099

119

100

2

0.120

144

169

3

0.115

138

160

4

0.148

178

218

5

0.158

190

212

6

0.102

122

222

7

0.131

157

Glucose Test Kit. Standard absorbance values were plotted versus glucose concentration and best line was drawn. Sample glucose values were determined from the sample absorbance values and the above standard curve.

b Serum from diabetic rats diluted 1:5, therefore glucose concentration from standard curve multiplied by 5 . 
TABLE 15.--Effect of STZ-induced Diabetes and of Food Restriction and Hypothyroidism on Serum Insulin of the SHR and WKY Rat. Raw Data.

\begin{tabular}{|c|c|c|}
\hline Assay 1 . & Insulin Standards ${ }^{\mathrm{a}}(\mu \mathrm{U} / \mathrm{m} 1)$ & CPM \\
\hline & 0 & 7882 \\
\hline & 10 & 7078 \\
\hline & 20 & 7239 \\
\hline & 40 & 6031 \\
\hline & 80 & 4549 \\
\hline & 160 & 3504 \\
\hline$\underline{\mathrm{SHR}}$ & CPM & Insulin $^{\mathrm{a}}(\mu \mathrm{U} / \mathrm{m} 1)$ \\
\hline
\end{tabular}

1

2

3

4

5

6

Diabetic

1

2

3

4

5

6

7

Food Restricted
5085

6483

7118

7345

7222

6599

7161

6323

7391

7151

7237

7434

7321

6511

$6817^{\circ}$
67.1

31.9

22.8

20.2

21.6

30.0

22.3

34.8

19.7

22.4

21.4

19.3

20.4

31.4

26.7 
TABLE 15 Continued

\begin{tabular}{|c|c|c|}
\hline 3 & 6529 & 31.1 \\
\hline 4 & 7677 & 16.9 \\
\hline 5 & 6945 & 25.0 \\
\hline WKY & CPM & Insulin $^{\mathrm{a}}(\mu \mathrm{U} / \mathrm{ml})$ \\
\hline \multicolumn{3}{|c|}{ Contro1 } \\
\hline 1 & 4486 & 92.9 \\
\hline 2 & 5307 & 59.6 \\
\hline 3 & 6625 & 29.6 \\
\hline 4 & 5207 & 62.9 \\
\hline 5 & 5129 & 65.5 \\
\hline 6 & 5739 & 47.4 \\
\hline \multicolumn{3}{|c|}{ Diabetic } \\
\hline 1 & 6730 & 28.0 \\
\hline 2 & 7038 & 23.8 \\
\hline 3 & 6894 & 25.7 \\
\hline 4 & 6231 & 36.5 \\
\hline 5 & 6322 & 34.8 \\
\hline 6 & 6896 & 25.6 \\
\hline \multicolumn{3}{|c|}{ Food Restricted } \\
\hline 1 & 7002 & 24.2 \\
\hline 2 & 6059 & 40.0 \\
\hline 3 & 7044 & 23.4 \\
\hline 4 & 6630 & 29.5 \\
\hline 5 & 7033 & 23.8 \\
\hline
\end{tabular}


TABLE 15 Continued

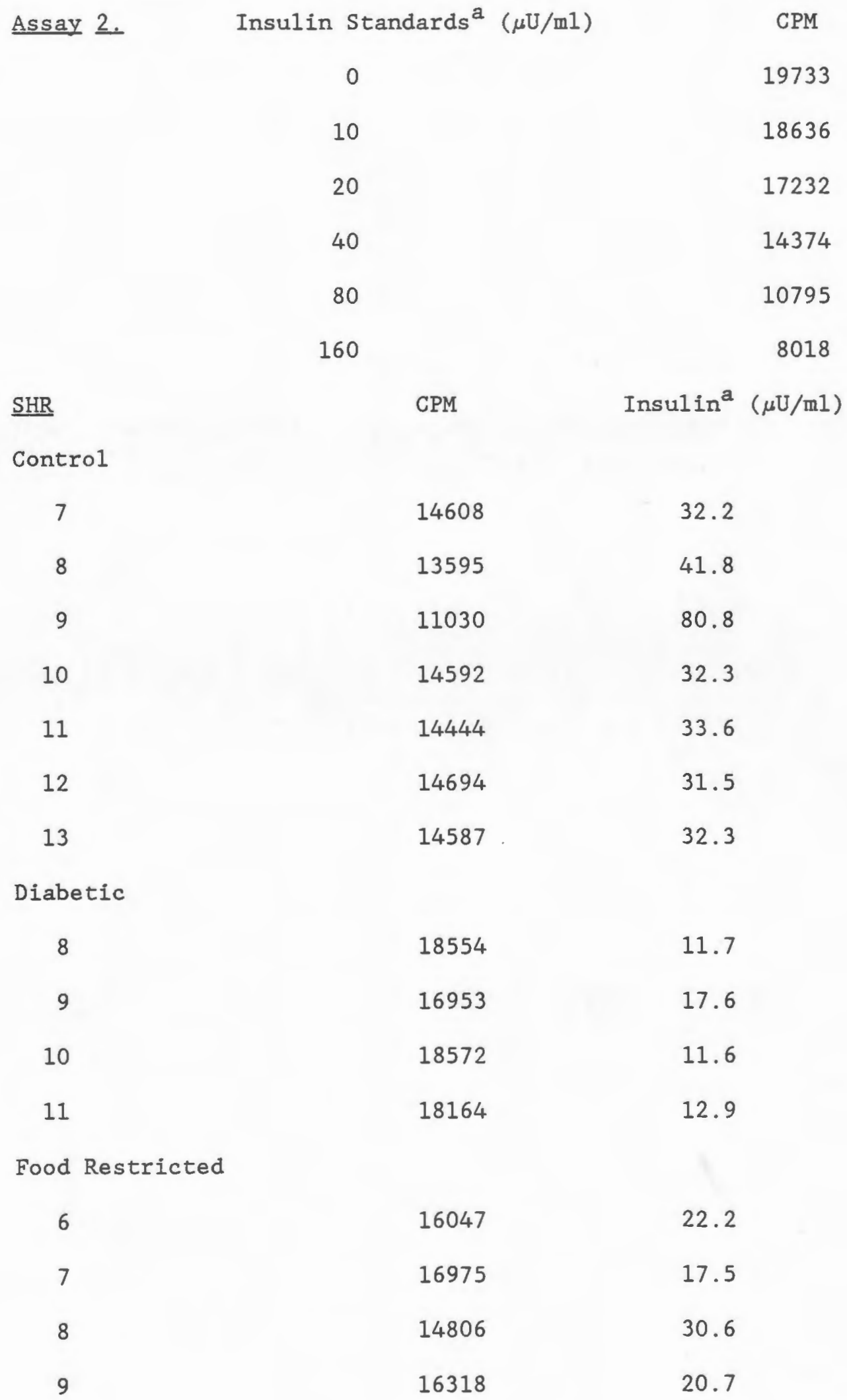


TABLE 15 Continued

Hypothyroid

\begin{tabular}{|c|c|c|}
\hline 1 & 14534 & 32.8 \\
\hline 2 & 16129 & 21.8 \\
\hline 3 & 16747 & 18.6 \\
\hline 4 & 12578 & 54.2 \\
\hline 5 & 16339 & 20.6 \\
\hline 6 & 13627 & 41.4 \\
\hline 7 & 16069 & 22.1 \\
\hline$\underline{\text { WKY }}$ & $\mathrm{CPM}$ & Insulin ${ }^{\mathrm{a}}(\mu \mathrm{U} / \mathrm{ml})$ \\
\hline \multicolumn{3}{|c|}{ Control } \\
\hline 7 & 13986 & 37.8 \\
\hline 8 & 10445 & 93.9 \\
\hline 9 & 14938 & 29.6 \\
\hline 10 & 9936 & 107.0 \\
\hline 11 & 14792 & 30.7 \\
\hline 12 & 13228 & 45.9 \\
\hline 13 & 12385 & 57.0 \\
\hline \multicolumn{3}{|c|}{ Diabetic } \\
\hline 7 & 17369 & 15.8 \\
\hline 8 & 15329 & 26.7 \\
\hline 9 & 15418 & 26.1 \\
\hline 10 & 17040 & 17.2 \\
\hline \multicolumn{3}{|c|}{ Food Restricted } \\
\hline 6 & 17289 & 16.1 \\
\hline 7 & 16526 & 19.6 \\
\hline 8 & 16515 & 19.7 \\
\hline
\end{tabular}


TABLE 15 Continued

\begin{tabular}{|c|c|}
\hline 0 & 16230 \\
\hline & 16313 \\
\hline
\end{tabular}

Hypothyroid

1

2

3

4

5

a serum insulin determined using Amersham's Insulin RIA Kit (Arlington Heights, I1.) Standard CPM values plotted versus log insulin concentration and best line drawn. Sample insulin values determined from sample CPM values and the above standard curve.
22.7

57.8

31.9

45.8

$\begin{array}{ll}14753 & 31.0\end{array}$ 
TABLE 16.--Effect of STZ-induced Diabetes and of Food Restriction and Hypothyroidism on Serum Thyroxine $\left(\mathrm{T}_{4}\right)$ of SHR and WKY Rat. Raw Data.

Assay 1.

\section{$\mathrm{T}_{4}$ Standards $^{\mathrm{a}}(\mu \mathrm{g} / \mathrm{d} \mathrm{l})$}

0

2.3

5.8

11.8

24.6

$\underline{\text { SHR }}$

Contro1

1

2

3

4

5

6

Diabetic

1

2

3

4

5

6

Food Restricted

1

2

3

4
CPM

6852

6285

6314

6860

5962

6622

8534

10258

8180

9006

9879

9693

6510

7342

7672

9204
CPM

12897

9889

6547

5255

3155

$\mathrm{T}_{4}^{\mathrm{a}}(\mu \mathrm{g} / \mathrm{d} 1)$
6.8

8.2

8.1

6.8

9.1

7.3

3.9

2.2

4.4

3.3

2.5

2.6

7.6

5.8

5.2

3.1 
TABLE 16 Continued

5

WKY

Control

1

2

3

4

5

Diabetic

1

2

3

4

5

Food Restricted

1

2

3

4

5

Assay 2 .

\section{6}

CPM

5649

6505

5970

6225

6723

7970

8351

7790

8543

7819

7740

7120

8742

7563

7775

$\mathrm{T}_{4}$ Standards $^{\mathrm{a}}(\mu \mathrm{g} / \mathrm{dI})$

0

2.3

5.8

11.8

24.6
4.2

$\mathrm{T}_{4}{ }^{\mathrm{a}}(\mu \mathrm{g} / \mathrm{dl})$

10.1

7.6

9.1

8.4

7.1

4.7

4.1

5.0

3.1

4.1

5.0

6.2

3.6

5.4

5.2

CPM

13856

10348

7423

5230

3527 
TABLE 16 Continued

$\underline{\text { SHR }}$

Control

7

8

9

10

Diabetic

7

Hypothyroid

1

2

3

4

5

6

7

WKY

Contro1

6

7

8

9

10

Diabetic

6
CPM

8290

7001

7466

6984

7053

10447

10175

10891

11514

10632

10935

10752

CPM

8072

7300

7349

7820

7218

8000
7.0

6.2

7. 2

$\mathrm{T}_{4}^{\mathrm{a}}(\mu \mathrm{g} / \mathrm{d} 1)$

4.8

7.1

2.4

2.6

2.1

1.7

2.3

2. 1

2.2

$\mathrm{T}_{4}^{\mathrm{a}}(\mu \mathrm{g} / \mathrm{d} 1)$

5.1

6.5

6.4

5.5

6.7

5.2 
TABLE 16 Continued

Hypothyroid

\begin{tabular}{|c|c|c|}
\hline 1 & 10313 & 2.5 \\
\hline 2 & 10340 & 2.5 \\
\hline 3 & 10318 & 2.5 \\
\hline 4 & 10497 & 2.4 \\
\hline 5 & 10464 & 2.4 \\
\hline 6 & 7820 & 5.5 \\
\hline 7 & 10823 & 2.1 \\
\hline \multirow[t]{6}{*}{ Assay 3 . } & $\mathrm{T}_{4}$ Standards $^{\mathrm{a}}(\mu \mathrm{g} / \mathrm{d} 1)$ & CPM \\
\hline & 0 & 5804 \\
\hline & 2.3 & 4527 \\
\hline & 5.8 & 3140 \\
\hline & 11.8 & 2189 \\
\hline & 24.6 & 1324 \\
\hline$\underline{\mathrm{SHR}}$ & $\mathrm{CPM}$ & $\mathrm{T}_{4}^{\mathrm{a}}(\mu \mathrm{g} / \mathrm{d} 1)$ \\
\hline \multicolumn{3}{|l|}{ Contro1 } \\
\hline 11 & 3031 & 6.7 \\
\hline 12 & 2988 & 6.9 \\
\hline 13 & 2720 & 8.4 \\
\hline \multicolumn{3}{|l|}{ Diabetic } \\
\hline 8 & 3737 & 4.1 \\
\hline 9 & 4077 & 3.2 \\
\hline 10 & 4052 & 3.2 \\
\hline \multicolumn{3}{|c|}{ Food Restricted } \\
\hline 6 & 3751 & 4.0 \\
\hline 7 & 3469 & 4.9 \\
\hline
\end{tabular}


TABLE 16 Continued

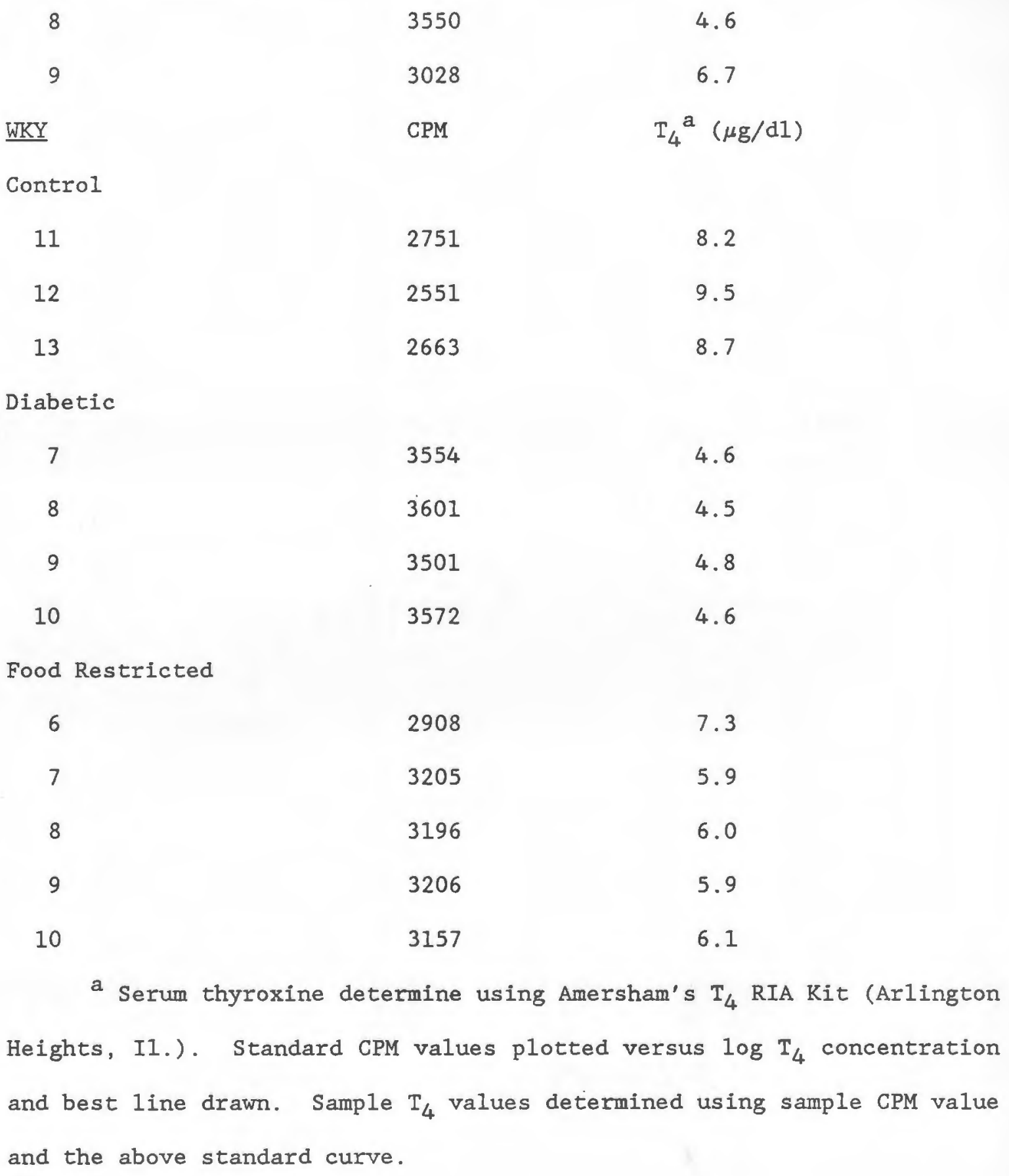


TABLE 17.--Effect of STZ-induced Diabetes and Food Restriction on Systolic Arterial Pressure (SAP) of the SHR and WKY Rat. Raw Data.

Week: ${ }^{a}$

$\underline{\text { SHR }}$

Control

1

2

3

4

5

6

7

8

9

Diabetic

1

2

3

4

5

6

7

8

9

10

11

12
0

2

4

$\mathrm{SAP}^{\mathrm{b}}$ (mm Hg)$$
\mathrm{SAP} \text { (mm Hg) }
$$

6

8

$\begin{array}{ccccc}150 & 156 & 180 & 161 & 190 \\ 202 & 193 & 203 & 199 & 215 \\ 185 & 182 & 190 & 210 & 234 \\ - & 213 & 147 & 222 & - \\ 170 & - & 176 & 196 & 171 \\ 215 & 206 & 218 & 233 & 248 \\ 170 & 194 & 189 & 188 & 216 \\ 180 & 170 & 168 & - & 194 \\ 160 & 163 & 193 & 193 & 176\end{array}$

148

223

254

190

170

215

224

213

173

163

253

185

158

203

155

139

164

118

146

148

140

136

130

158

164

139

143

197

183

170

180

211

144

118

160

110 
TABLE 17 Continued

Food Restricted

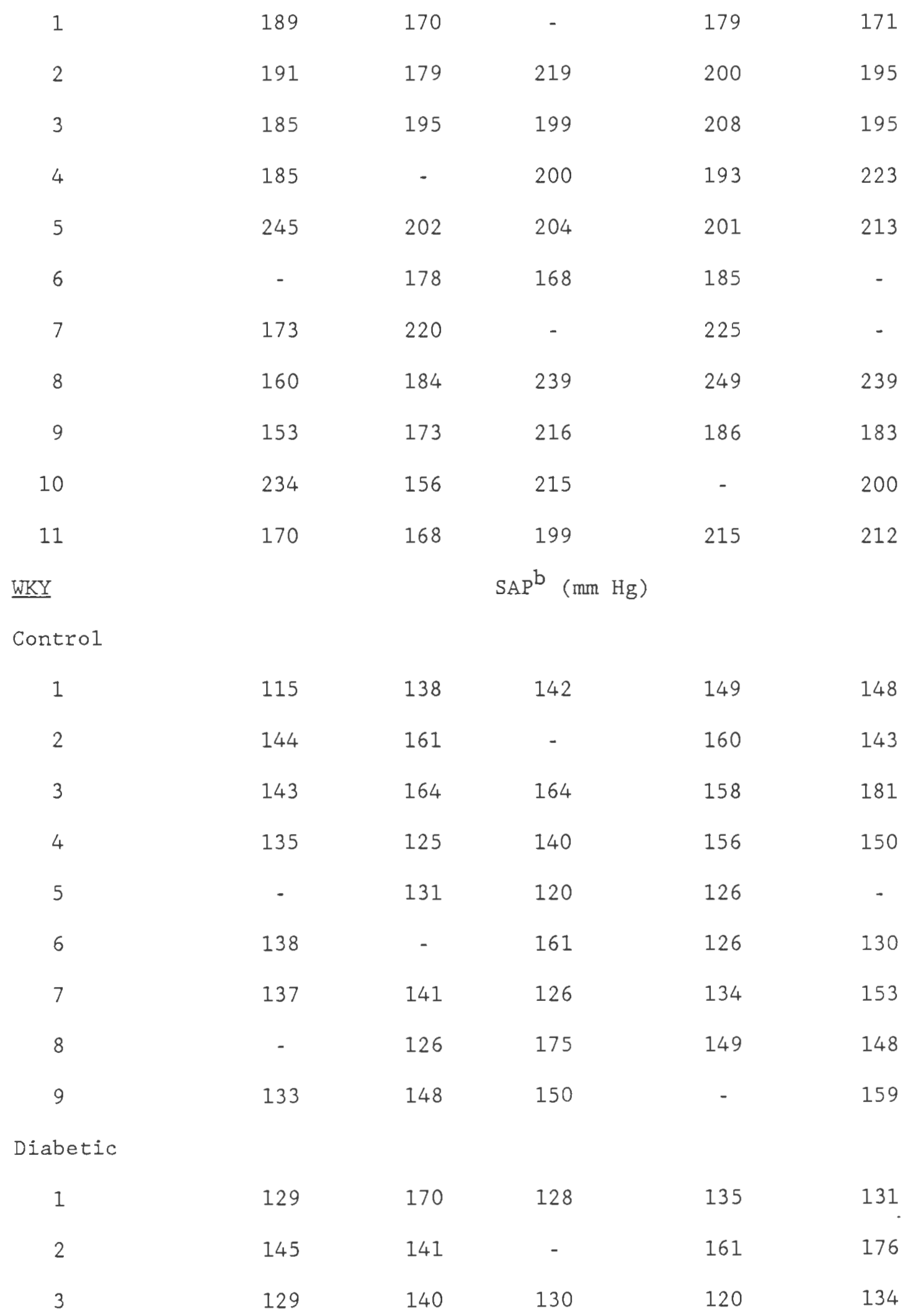


TABLE 17 Continued

$\begin{array}{lccccc}4 & - & 161 & 131 & 115 & - \\ 5 & 144 & 139 & 131 & 143 & 130 \\ 6 & 126 & - & 166 & 116 & 125 \\ 7 & 108 & 129 & 123 & 144 & 143 \\ 8 & - & 147 & 120 & 136 & 134 \\ 9 & 144 & 119 & 121 & 134 & 140 \\ 10 & 129 & 145 & 136 & - & 128\end{array}$

Food Restricted

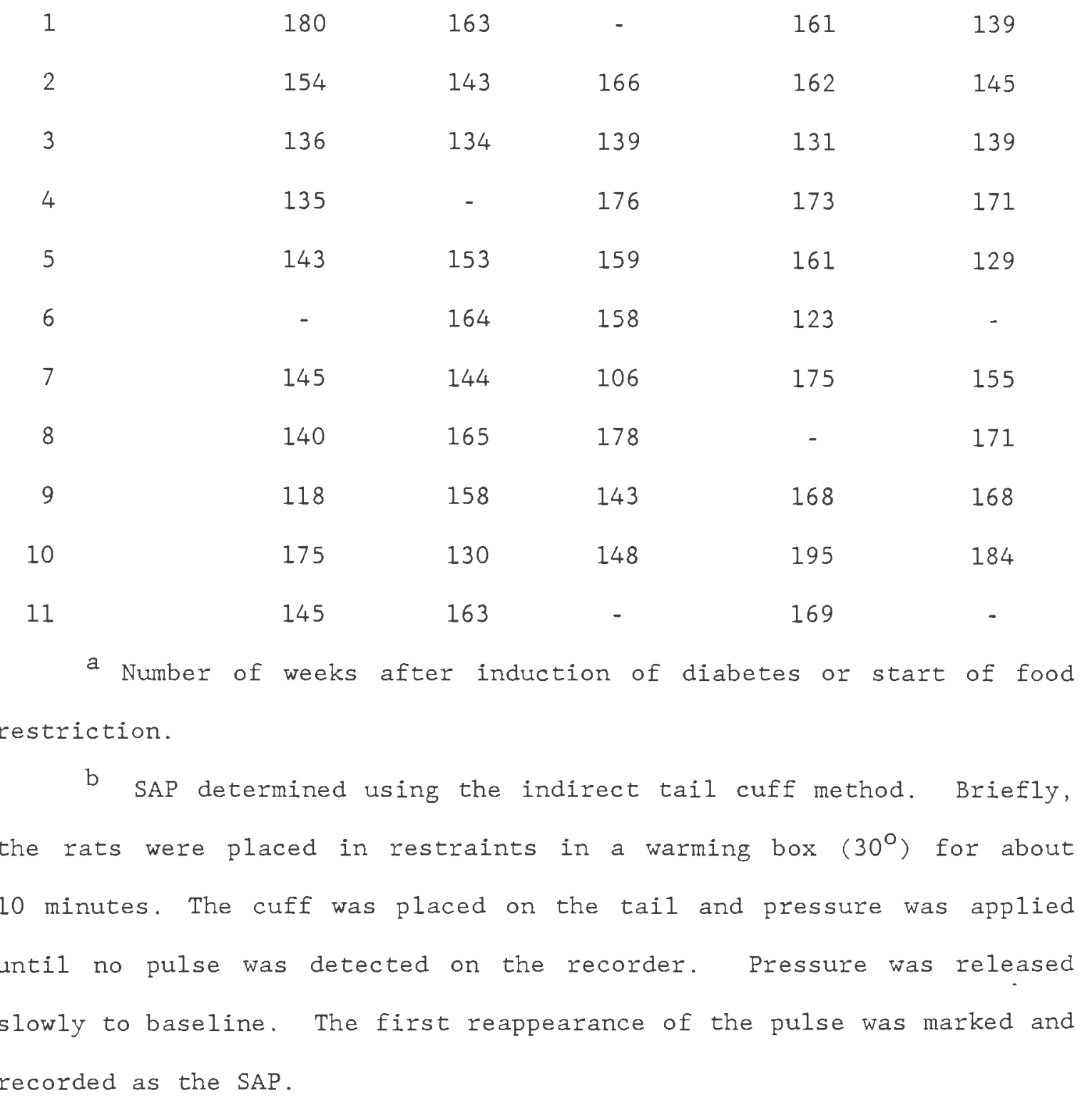


TABLE 18.--Effect of STZ-induced Diabetes and of Food Restriction and Hypothyroidism on Prolyl Hydroxylase Activity in the Aorta of the SHR and WKY Rat. Raw Data.

\begin{tabular}{|c|c|c|c|c|}
\hline Assay 1 . & Tissue & $\mathrm{CPM}^{\mathrm{a}}$ & $\mathrm{CPM} / \mathrm{mg}$ tissue ${ }^{\mathrm{b}}$ & $\mathrm{CPM} / \mathrm{mg}$ protein ${ }^{\mathrm{c}}$ \\
\hline$\underline{\text { SHR }}$ & Weight mg & & & \\
\hline \multicolumn{5}{|l|}{ Contro1 } \\
\hline 1 & 47.3 & 1385 & $146^{\circ}$ & 3617 \\
\hline 2 & 37.7 & 1242 & 165 & 5010 \\
\hline 3 & 45.0 & 1298 & 144 & 4898 \\
\hline 4 & 40.5 & 1093 & 135 & 3729 \\
\hline 5 & 33.1 & 1012 & 153 & 4986 \\
\hline \multicolumn{5}{|l|}{ Diabetic } \\
\hline 1 & 32.4 & 163 & 25 & 1548 \\
\hline 2 & 49.4 & 68 & 7 & 628 \\
\hline 3 & 41.1 & 74 & 9 & 827 \\
\hline 4 & 46.0 & 187 & 20 & 1735 \\
\hline 5 & 42.4 & 275 & 32 & 1964 \\
\hline \multicolumn{5}{|c|}{ Food Restricted } \\
\hline 1 & 40.2 & 1023 & 127 & 2982 \\
\hline 2 & 45.9 & 673 & 73 & 2022 \\
\hline 3 & 48.2 & 779 & 81 & 2940 \\
\hline 4 & 30.6 & 587 & 96 & 5193 \\
\hline 5 & 50.5 & 884 & 88 & 2491 \\
\hline
\end{tabular}

WKY

Control

1

2

3
33.5

24.8

41.2
676

454

774
101

92

94
2941

4637

4422 
TABLE 18 Continued
4
37.4
553
74
2323

Diabetic

$\begin{array}{rrrrr}1 & 49.2 & 328 & 33 & 2297 \\ 2 & 27.8 & 220 & 40 & 2314 \\ 3 & 28.9 & 202 & 35 & 1838 \\ 4 & 38.8 & 353 & 46 & 2827\end{array}$

Food Restricted

\begin{tabular}{|c|c|c|c|c|}
\hline 1 & 25.7 & 420 & 82 & 1728 \\
\hline 2 & 20.8 & 240 & 58 & 2664 \\
\hline 3 & 20.7 & 223 & 54 & 2349 \\
\hline 4 & 26.3 & 381 & 73 & 3632 \\
\hline 5 & 55.7 & 748 & 67 & 4451 \\
\hline Assay 2 . & Tissue & $\mathrm{CPM}^{\mathrm{a}}$ & $\mathrm{CPM} / \mathrm{mg}$ tissue ${ }^{\mathrm{b}}$ & $\mathrm{CPM} / \mathrm{mg}$ protein ${ }^{\mathrm{C}}$ \\
\hline$\underline{\mathrm{SHR}}$ & Weight mg & & & \\
\hline \multicolumn{5}{|l|}{ Control } \\
\hline 6 & 49.9 & 890 & 89 & 2871 \\
\hline 7 & 25.8 & 564 & 109 & 3133 \\
\hline 8 & 28.2 & 464 & 82 & 2730 \\
\hline 9 & 43.9 & 1110 & 126 & 2920 \\
\hline \multicolumn{5}{|c|}{ Hypothyroid } \\
\hline 1 & 27.8 & 382 & 69 & 2181 \\
\hline 2 & 33.7 & 466 & 69 & 2218 \\
\hline 3 & 45.6 & 556 & 61 & 1764 \\
\hline 4 & 43.0 & 593 & 69 & 2325 \\
\hline 5 & 33.3 & 348 & 52 & 1512 \\
\hline 6 & 40.6 & 464 & 57 & 1974 \\
\hline 7 & 44.2 & 654 & 74 & 2324 \\
\hline
\end{tabular}


TABLE 18 Continued

WKY

Control

7

8

8

38.7

357

46

1878

18.0

159

44

1676

20.6

128

31

1342

460

65

2966

Hypothyroid

$\begin{array}{rrrrr}1 & 37.4 & 338 & 45 & 1649 \\ 2 & 36.7 & 226 & 31 & 1253 \\ 3 & 36.7 & 276 & 38 & 1723 \\ 4 & 20.4 & 77 & 19 & 644 \\ 5 & 36.4 & 261 & 36 & 1683 \\ 6 & 20.4 & 61 & 15 & 581 \\ 7 & 40.5 & 166 & 20 & 1143\end{array}$

a Prolyl hydroxylase activity determined by the method of Hutton et al, 1966. Briefly, the aorta was homogenized in $1 \mathrm{~m} 1$ buffer containing sucrose $(0.25 \mathrm{M})$, tris $(0.05 \mathrm{M})$, EDTA $\left(10^{-5} \mathrm{M}\right)$, DL-dithiothreitol $\left(10^{-5} \mathrm{M}\right)$, and triton-100 in a ground glass homogenizer. Tissue homogenate was centrifuged at $15,000 \mathrm{x} g$ for 15 minutes. An aliquot $(200 \mu 1)$ of supernatant was placed in a $10 \times 75 \mathrm{~mm}$ tube with $800 \mu 1$ of reaction mixture containing tris, ascorbic acid, iron, bovine serum albumin, catalase, $\alpha$-ketogluterate, and ${ }^{3} \mathrm{H}$-proline. The tubes were incubated in a $30^{\circ} \mathrm{C}$ water bath for 30 minutes. At the end of thirty minutes, $100 \mu 1$ of 508 trichloroacetic acid was added to each tube to stop the reaction. The tritiated water formed during the incubation was collected by vacuum distillation. An aliquot $(800 \mu 1)$ of distillate was counted in a liquid scintillation counter for ten minutes and the CPMs recorded. calculation is (CPM $\mathrm{x} 5) \div$ tissue weight (mg)

c calculation is (CPM $\times 5) \div$ protein (mg) per $m 1$ of supernatant 
TABLE 19.--Lowry Protein Assay. Raw Data.

Assay 1.

BSA Standards ${ }^{a} \mu g$ Absorbance ${ }^{b}$ a750nm $\operatorname{Protein}^{c}$ (mg) $\operatorname{Protein}^{\mathrm{d}}(\mathrm{mg}) / \mathrm{m} 1$

$\begin{array}{ll}2 & 0.032 \\ 5 & 0.078 \\ 10 & 0.142 \\ 20 & 0.255 \\ 30 & 0.351 \\ 40 & 0.432 \\ 50 & 0.488\end{array}$

$\underline{\text { SHR }}$

Control

1

2

3

4

5

Diabetic

1

2

3

4

5

Food Restricted

1

2

3

4

0.438

0.0383

1.915

0.318

0.382

0.381

0.326

0.200

0.173

0.150

0.174

0.235

0.443

0.0343

1.715

0.411

0.0333

1.665

0.383

0.180 
TABLE 19 Continued

5

WKY

Control

1

2

3

4

Diabetic

1

2

3

4

Food Restricted

1

2

3

4

5

Assay 2.

BSA Standards ${ }^{a} \mu \mathrm{g}$ Absorbance ${ }^{b}\left({ }^{2} 750 \mathrm{~nm}\right.$

5

10

20

30

40

50

0.429

0.320

0.206

0.279

0.362

0.223

0.172

0.184

0.221

0.359

0.155

0.178

0.180

0.275

.
0.084

0.156

0.269

0.380

0.455

0.529

0.0355

1.775

0.0230

1.150

0.0098

0.490

0.0175

0.875

0.0238

1.190

0.0143

0.715

0.0095

0.475

0.0110

0.550

0.0125

0.625

0.0243

1. 215

0.0090

0.450

0.0095

0.475

0.0105

0.525

0.0168

0.840

$\operatorname{Protein}^{\mathrm{c}}(\mathrm{mg}) \quad$ Protein $^{\mathrm{d}}(\mathrm{mg} / \mathrm{ml})$ 
TABLE 19 Continued

SHR

Control

6

7

8

9

Hypothyroid

1

2

3

4

5

6

7

WKY

Control

5

6

7

8

Hypothyroid

1

2

3

4

5

6

7

(n)

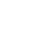

0.388

0.251

0.236

0.447

0.247

0.284

0.394

0.340

0.307

0.310

0.346
0.0310

0.0180

0.0170

0.0380

0.0175

0.0210

0.0315

0.0255

0.0230

0.0235

0.0270

1.550

0.900

0.850

1.900
0.875

1.050

1.575

1.275

1. 150

1.175

1. 350

0.265

0.0190

0.950

0.145

0.0095

0.475

0.145

0.0095

0.475

0.220

0.0155

0.775

0.277

0.0205

1.025

0.249

0.0180

0.900

0.228

0.0160

0.800

0.180

0.0120

0.600

0.221

0.0155

0.775

0.154

0.0105

0.525

0.209

0.0145

0.725

a Standard curve determined for each assay.

A bovine serum albumin stock ( $1 \mathrm{mg} / \mathrm{ml}$ ) was used and appropiate aliquots removed to give the listed BSA concentration. Each aliquot was diluted to $100 \mu 1$ with $1 \mathrm{~N} \mathrm{NaOH}$.

$b$ Protein determined by the method of Lowry et al, 1952. Briefly, an aliquot $(20 \mu 1)$ of the supernatant of the tissue homogenate from the prolyl hydroxylase assay was placed in $10 \times 75 \mathrm{~mm}$ tubes. The aliquots were diluted to $100 \mu 1$ with $1 \mathrm{~N} \mathrm{NaOH}$. To each standard and sample tube 
TABLE 19 Continued

$1 \mathrm{~m} 1$ of solution D $\left(49.0 \mathrm{mls} 2 \% \mathrm{Na}_{2} \mathrm{CO}_{3}, 0.5 \mathrm{ml} 2 \% \mathrm{Na}\right.$ Tartrate, $0.5 \mathrm{ml}$ $\left.18 \mathrm{CuSO}_{4}\right)$ was added. After waiting 20 minutes, $100 \mu 1$ of $1 \mathrm{~N}$ Folin Phenol Reagent was added to all standard and sample tubes. The tubes were mixed. After 40 minutes, the absorbance of each tube @ $750 \mathrm{~nm}$ was read. c Determined from the standard curve using the absorbance values. d Calculation is protein (mg) x 50 . 
TABLE 20.--Effect of STZ-induced Diabetes and of Food Restriction and Hypothyroidism on the Sensitivity $\left(\mathrm{pD}_{2}\right)$ of the Mesenteric Artery of the SHR and WKY Rat. Raw Data.

\begin{tabular}{|c|c|c|}
\hline & & $\mathrm{pD}_{2}$ \\
\hline Agonist: & $\mathrm{Ne}$ & $5 \mathrm{HT}$ \\
\hline
\end{tabular}

Control

$\begin{array}{llll}1 & 6.44 & 6.17 & 5.20 \\ 2 & 6.73 & 6.35 & 5.52 \\ 3 & 6.73 & 6.30 & 5.44 \\ 4 & 6.30 & 6.30 & 5.00 \\ 5 & 7.00 & 6.25 & 5.24 \\ 6 & 6.35 & 6.05 & 4.98 \\ 7 & 6.78 & 6.30 & 5.22 \\ 8 & 7.05 & 6.13 & 5.04 \\ 9 & 6.43 & 6.30 & 5.26 \\ 10 & 6.43 & 6.37 & 5.20\end{array}$

Diabetic

1

$6.72 \quad 6.05$

5.35

2

6.98

6.42

5.62

3

6.50

6.28

6.02

4

6.40

6.22

5.50

5

6.94

6.45

5.76

6

6.65

6.14

5.30

7

6.25

6.30

5.35

8

6.10

6.05

5.35 
TABLE 20 Continued

Food Restricted

1

2

3

4

5

6

7

8

Hypothyroid

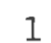

2

3

4

5

6

7

WKY

Control

1

2

\section{3}

4

5

6

7

8
7.15

7.10

6.58

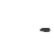

6.84

6.28

6.30

6.05

6.38

7.50

6.90

6.70

6.58

6.68

6.56
6.50

6.86

6.50

6.56

6.75

6.38

6.40

6.38

6.02

6.02

6.14

6.16

6.20

6.02

5.90
5.75

5.82

5.66

5.38

5.32

5.34

5.28

5.30

5.02

4.95

5.15

5.15

5.08

4.95

5.28

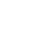


TABLE 20 Continued

Diabetic

1

2

3

4

5

6

7

Food Restricted

1

2

3

4

5

6

7

Hypothyroid

1

2

3

4

5

6

7
6.34

6.60

6.65

6.65

6.35

6.14

6.98

7.10

6.45

7.35

6.55

6.45

6.40

6.45

6.55

5.96

5.70

5.86

5.80

5.78

5.74

5.54
5.15

5.42

5.36

5.52

5.35

5.38

5.55

5.55

5.50

5.84

5.45

5.58

5.52

5.45
6.38

6.50

6.40

6.50

6.54

6.30

a Determined from the $-\log \mathrm{ED}_{50}$. to produce $50 \%$ of the maximum response. Dose response curves were determined using the following procedure. The mesenteric artery was 
TABLE 20 Continued

isolated and a $2 \mathrm{~cm}$ piece was removed and placed in $100 \mathrm{ml}$ of oxygenated ( $\left(958 \mathrm{O}_{2}-58 \quad \mathrm{CO}_{2}\right)$ Krebs-Henseliet buffer of the following composition (mM): $\mathrm{NaCl}$ (113), $\mathrm{KCL}$ (4.7), $\mathrm{CaCl}_{2}$ (2.5), $\mathrm{KH}_{2} \mathrm{PO}_{4}$ (1.2), $\mathrm{MgSO}_{4}$ (1.2), Glucose (11.5), $\mathrm{NaHCO}_{3}$ (19). Fat was carefully trimmed from the mesenteric artery so as to not stretch or damage the vessel. A 3 - $5 \mathrm{~mm}$ ring was cut and placed on two platinum hooks. The vessel was placed in a jacketed tissue chamber containing $100 \mathrm{ml}$ oxygenated $\mathrm{KH}$ buffer maintained at $37^{\circ} \mathrm{C}$. The bottom platinum hook was secured in the tissue chamber and the top hook was attached to a Grass FT03 forcedisplacement transducer. One gram of tension was placed on the vessel, and it was allowed to equilibrate for 90 minutes. The buffer was changed every thirty minutes throughout the experiment. The vasoactive agents employed were norepinephrine (NE), 5-hydroxytryptamine (5HT), and methoxamine (MOX). Cocaine $\left(10^{-6} \mathrm{M}\right)$ was added to the buffer to prevent reuptake of norepinephrine (Webb and Vanhoutte, 1981). Developed tension responses were obtained over a range of $10^{-9} \mathrm{M}$ to $10^{-4} M$ for $N E$ and over a range of $10^{-7} M$ to $10^{-4} M$ for $5 \mathrm{HT}$ and methoxamine. A sixty minute period with frequent buffer changes was employed between agonist dose response curves. 
TABLE 21.--Effect of STZ-induced Diabetes and of Food Restriction and Hypothyroidism on Responsiveness of the Mesenteric Artery of the SHR and WKY Rat. Raw Data.

Maximum Change in Tension ${ }^{\mathrm{a}}$ (mg)

$\begin{array}{ccccc}\text { Tissue } & \text { NE } & \text { 5HT } & \text { MOX } & \text { KCL } \\ \text { Weight (mg) } & 10^{-4} \mathrm{M} & 10^{-4} \mathrm{M} & 10^{-4} \mathrm{M} & 100 \mathrm{mM}\end{array}$

$\underline{\text { SHR }}$

Control

$\begin{array}{llllll}1 & 0.98 & 530 & 650 & 550 & 500 \\ 2 & 1.01 & 650 & 890 & 690 & 290 \\ 3 & 0.98 & 470 & 640 & 510 & 330 \\ 4 & 1.47 & 700 & 750 & 550 & 400 \\ 5 & 0.34 & 450 & 500 & 400 & 200 \\ 6 & 0.53 & 610 & 640 & 480 & 250 \\ 7 & 0.55 & 700 & 760 & 730 & 480 \\ 8 & 0.57 & 700 & 920 & 860 & 500 \\ 9 & 0.86 & 600 & 780 & 700 & 420\end{array}$

Diabetic

$\begin{array}{rrrrrr}1 & 1.05 & 1550 & 1600 & 1300 & 700 \\ 2 & 0.90 & 700 & 1000 & 730 & 400 \\ 3 & 0.61 & 660 & 760 & 710 & 350 \\ 4 & 0.62 & 820 & 900 & 1000 & 600 \\ 5 & 0.55 & 400 & 200 & 300 & 250 \\ 6 & 0.49 & 850 & 1100 & 1010 & 500 \\ 7 & 0.45 & 800 & 800 & 820 & 400 \\ 8 & 0.93 & 1150 & 700 & 820 & 400\end{array}$


TABLE 21 Continued

Food Restricted

$\begin{array}{rrrrrr}1 & 1.00 & 1000 & 900 & 430 & 200 \\ 2 & 1.35 & 1320 & 1500 & 1600 & 1050 \\ 3 & 0.60 & 520 & 800 & 880 & 650 \\ 4 & 0.46 & 450 & 580 & 500 & 200 \\ 5 & 0.60 & 540 & 750 & 870 & 450 \\ 6 & 0.78 & 780 & 1000 & 820 & 500 \\ 7 & 0.57 & 690 & 900 & 840 & 510 \\ 8 & 0.72 & 920 & 1260 & 1260 & 650\end{array}$

Hypothyroid

$\begin{array}{llllll}1 & 0.66 & 810 & 860 & 720 & 430 \\ 2 & 0.84 & 530 & 550 & 430 & 300 \\ 4 & 0.97 & 580 & 610 & 600 & 500 \\ 5 & 0.87 & 680 & 770 & 750 & 460 \\ 6 & 0.65 & 710 & 810 & 760 & 270 \\ 7 & 0.73 & 690 & 740 & 660 & 350 \\ & 0.68 & 840 & 950 & 920 & 550\end{array}$

WKY

Control

$\begin{array}{llllll}1 & 0.43 & 600 & 750 & 820 & 570 \\ 2 & 0.60 & 530 & 500 & 430 & 200 \\ 3 & 0.52 & 580 & 460 & 510 & 250 \\ 4 & 0.58 & 650 & 730 & 660 & 300 \\ 5 & 0.54 & 670 & 530 & 490 & 260 \\ 6 & 0.52 & 590 & 500 & 410 & 180 \\ 7 & 0.22 & 500 & 500 & 500 & 300 \\ 8 & 0.40 & 830 & 870 & 970 & 430\end{array}$


TABLE 21 Continued

Diabetic

$\begin{array}{rrrrrr}1 & 1.12 & 600 & 570 & 630 & 520 \\ 2 & 0.93 & 930 & 1040 & 1210 & 690 \\ 3 & 0.53 & 770 & 780 & 720 & 320 \\ 4 & 0.54 & 1150 & 1400 & 1490 & 750 \\ 5 & -0.79 & 1100 & 1190 & 1280 & 550 \\ 6 & 0.57 & 1180 & 1240 & 1430 & 910 \\ 7 & 0.37 & 740 & 590 & 660 & 200\end{array}$

Food Restricted

$\begin{array}{rrrrrr}1 & 0.88 & 600 & 550 & 650 & 450 \\ 2 & 0.40 & 730 & 850 & 700 & 400 \\ 3 & 0.58 & 950 & 1150 & 1250 & 620 \\ 4 & 0.49 & 850 & 910 & 1000 & 400 \\ 5 & 0.71 & 880 & 1150 & 1130 & 500 \\ 6 & 0.69 & 750 & 830 & 930 & 360 \\ 7 & 0.80 & 890 & 920 & 1250 & 730\end{array}$

Hypothyroid

$\begin{array}{llllll}1 & 0.37 & 650 & 370 & 390 & 180 \\ 2 & 0.89 & 540 & 220 & 330 & 150 \\ 3 & 0.47 & 620 & 500 & 400 & 180 \\ 4 & 0.82 & 840 & 580 & 730 & 210 \\ 5 & 0.66 & 480 & 330 & 440 & 190 \\ 6 & 0.78 & 710 & 580 & 550 & 180 \\ 7 & 0.53 & 1010 & 600 & 500 & 240\end{array}$

a Maximum change in tension reported is the response observed for the agonist concentration 1isted. Dose response curves were determined using the following procedure. The mesenteric artery was isolated and 
TABLE 21 Continued

a $2 \mathrm{~cm}$ piece was removed and placed in $100 \mathrm{ml}$ of oxygenated $\left(958 \mathrm{O}_{2}\right.$ $5 \% \mathrm{CO}_{2}$ ) Krebs-Henseliet buffer of the following composition (mM): NaCl (113), $\mathrm{KCL}(4.7), \mathrm{CaCl}_{2}(2.5), \mathrm{KH}_{2} \mathrm{PO}_{4}(1.2), \mathrm{MgSO}_{4}$ (1.2), Glucose (11.5), $\mathrm{NaHCO}_{3}$ (19). Fat was carefully trimmed from the mesenteric artery so as to not stretch or damage the vessel. A 3 - $5 \mathrm{~mm}$ ring was cut and placed on two platinum hooks. The vessel was placed in a jacketed tissue chamber containing $100 \mathrm{ml}$ oxygenated $\mathrm{KH}$ buffer maintained at $37^{\circ} \mathrm{C}$. The bottom platinum hook was secured in the tissue chamber and the top hook was attached to a Grass FT03 force-displacement transducer. One gram of tension was placed on the vessel, and it was allowed to equilibrate for 90 minutes. The buffer was changed every thirty minutes throughout the experiment. The vasoactive agents employed were norepinephrine (NE), 5-hydroxytryptamine (5HT), and methoxamine (MOX). Cocaine $\left(10^{-6} \mathrm{M}\right)$ was added to the buffer to prevent reuptake of norepinephrine (Webb and Vanhoutte, 1981). Developed tension responses were obtained over a range of $10^{-9} \mathrm{M}$ to $10^{-4} \mathrm{M}$ for $\mathrm{NE}$ and over a range of $10^{-7} \mathrm{M}$ to $10^{-4} \mathrm{M}$ for $5 \mathrm{HT}$ and methoxamine. Developed tension response was also obtained for $\mathrm{KCl}(100 \mathrm{mM})$. A sixty minute period with frequent buffer changes was employed between agonist dose response curves. 


\section{BIBLIOGRAPHY}

Agrawal, D.K.; Triggle, C.R.; Daniel, E.E. Pharmacological characterization of the postsynaptic alpha adrenoceptors in vascular smooth muscle from canine and rat mesenteric vascular beds. J. Pharmacol. Exp. Ther. 229:831-838, 1984.

Albrecht, I.; Hallback, M.; Julius, S. Arterial pressure cardiac output and systemic resistance before and after pithing in normotensive and spontaneously hypertensive rats. Acta Physiol. Scand. 94:378 - $385,1975$.

Altman, J.; DaPonte, F.; Worcel, M. Evidence for a visceral smooth muscle abnormality in Okamoto spontaneous hypertension. Br. J. Pharmaco1. 59:621-625, 1977.

Arendshorst, W.J. and Beierwaltes, W.H. Renal and nephron hemodynamics in spontaneously hypertensive rats. Am. J. Physiol. 236:F246 $251,1979$.

Asano, M.; Aoki, K.; Matsuda, T. Quantitative changes of maximum contractile response to norepinephrine in mesenteric arteries from spontaneously hypertensive rats during the development of hypertension. J. Cardiovasc. Pharmacol. 6:727 - 731, 1984.

Bagby, S.P.; McDonald, W.J.; Mass, R.D. Serial renin-angiotensin studies in spontaneously hypertensive and Wistar-Kyoto rats. Transition from normal- to high-renin status during the established phase of spontaneous hypertension. Hypertension 1:347 $354,1979$. 
Berthelsen, S. and Pettinger, W.A. A functional basis for classification of $\alpha$-adrenergic receptors. Life Sciences 21:595 - 606, 1977.

Bhattacharya, B.K.; Dadkar, N.K.; Dohadwalla, A.N. Vascular reactivity of perfused vascular bed in spontaneously hypertensive and normotensive rats. Br. J. Pharmacol. 59:243 - 246, 1977.

Blumentha1, S.J.; McConnaughby, M.M.; Iams, S.G. Hypothyroidism lowers blood pressure, adenylate cyclase and $\mathrm{Na}, \mathrm{K}$ and $\mathrm{K}, \mathrm{Ca}$-ATPase activities in normotensive and spontaneously hypertensive rats. Experientia 38:707 - 709, 1982 .

Carney, S.L.; Wong, N.L.M.; Dirks, J.H. Acute effects of streptozotocin diabetes on rat renal function. J. Lab. C1in. Med. 93:950 - 961, 1979.

Cavaliere, T.A.; Taylor, D.G.; Kerwin, L.J.; Antonaccio, M.J. Cardiovascular effects of alloxan diabetes in normotensive and spontaneously hypertensive rats. Pharmacology 20:211 - 223, 1980.

Christlieb, A.R. Diabetes and hypertensive vascular disease. Am. J. Cardiol. $32: 592-606,1973$.

Collis, M.G. and Vanhoutte, P.M. Vascular reactivity of isolated perfused kidneys from male and female spontaneously hypertensive rats. Circ. Res. 41:759-767, 1977.

Colucci, W.S.; Gimbrone, M.A.; Alexander, R.W. Characterization of postsynaptic alpha-adrenergic receptors by [ $\left.{ }^{3} \mathrm{H}\right]-\mathrm{Di}$ hydroergocryptine binding in the muscular arteries from the rat mesentery. Hypertension 2:149 - 155, 1980.

Daniel, E.E.; Grover, A.K.; Kwan, C.Y. Isolation and properties of plasma membrane from smooth muscle. Fed. Proc. Fed. Am. Soc. Exp. Biol. 41:2898 - 2904, 1982. 
Ehrhart, L.A. and Ferrario, C.M. Collagen metabolism and reversal of aortic medial hypertrophy in spontaneously hypertensive rats treated with methyldopa. Hypertension 3:479 - 484, 1981.

Folkow, B.; Hallback, M.; Lundgren, Y.; Weiss, L. The effects of immunosympathectomy on blood pressure and vascular reactivity in normal and spontaneously hypertensive rats. Acta Physiol. Scand. $84: 512-523,1972$.

Forman, B.H. and Mulrow, P.J. Effect of propranolol on blood pressure and plasma renin activity in the spontaneously hypertensive rat. Circ. Res. 35:215 - 221, 1974.

Gilligan, J.P.; and Spector, S. Synthesis of collagen in cardiac and vascular walls. Hypertension Suppl. III 6:44 - 49, 1984.

Godfraind, T.; Miller, R.C.; Lima, J.S. Selective $\alpha_{1}{ }^{-}$and $\alpha_{2}{ }^{-}$ adrenoceptor agonist-induced contractions and ${ }^{45} \mathrm{Ca}$ fluxes in the rat isolated aorta. Br. J. Pharmacol. 77:597 - 604, 1982.

Haeusler, G. and Finch, L. Vascular responses to 5-hydroxytryptamine and hypertension in the rat. Naunyn-Schmied. Arch. Pharmacol. $272: 101-116,1972$.

Haeusler, G. and Haesfely, W. Pre and postjunctional supersensitivity of the mesenteric artery preparation from normotensive and hypertensive rats. Naunyn-Schmied. Arch. Pharmacol. 266: 18-33, 1970.

Henrich, H.; Hertel, R.; Assmann, R. Structural differences in the mesentery microcirculation between normotensive and spontaneously hypertensive rats. Pflugers Arch. 375: 153 - 160, 1978.

Hermsmeyer, K. Electrogenesis of increased norepinephrine sensitivity of arterial smooth muscle in hypertension. Circ. Res. 38:362 $367,1976$. 
Hutton, J.J.; Tappel, A.I.; Udenfriend, S. A rapid assay for collagen proline hydroxylase. Anal. Biochem. 16: 384 - 394, 1966.

Ishac, E.J.N. and Pennefather, J.N. The influence of the thyroid state upon responses to noradrenaline and phentolamine in perfused mesenteric arterioles from the rat. J. Pharm. Pharmacol. 35:466 - 468, 1983.

Iwatsuki, K.; Cardinale, G.J.; Spector, S.; Udenfriend, S. Hypertension: increase in collagen biosynthesis in arteries but not veins. Science 198:403 - 405, 1977.

Jackson, C.V. and Carrier, G.O. Supersensitivity of isolated mesenteric arteries to noradrenaline in the long-term experimental diabetic rat. J. Auton. Pharmacol. 1:399-405, 1981.

Jackson, C.V. and Carrier, G.O. Influence of short term experimental diabetes on blood pressure and heart rate in response to norepinephrine and angiotensin II in the conscious rat. J. Cardiovasc. Pharmacol. 5:260 - 265, 1983.

Jones, A.W. Altered ion transport in vascular smooth muscle from spontaneously hypertensive rats. Influences of aldosterone, norepinephrine, and angiotensin. Circ. Res. 33:563 - 572, 1973.

Judy, W.V.; Watanabe, A.M.; Murphy, W.R.; Aprison, B.S.; and Yu, P.L. Sympathetic nerve activity and blood pressure in normotensive backcross rats genetically related to the spontaneously hypertensive rat. Hypertension 1:598 - 604, 1979.

Kohler, L.; Biollat, N.; Luthi, P.; Atkinson, J.; Peters-Haefeli, I. Influence of streptozotocin-induced diabetes on blood pressure and on renin formation and release. Naunyn Schmied. Arch. Pharmacol. $313: 257-261,1980$. 
Koike, H; Ito, K.; Miyamoto, M.; Nishino, H. Effects of long-term blockade of angiotensin converting enzyme with captopril (SQ 14,225 ) on hemodynamics and circulating blood volume in SHR. Hypertension $2: 299-303,1980$.

Kwan, C.Y. Dysfunction of calcium handing by smooth muscle in hypertension. Can. J. Physiol. Pharmacol. 63:366 - 374, 1985.

Kwan, C.Y.; Belbeck, L.; Daniel, E.E. Abnormal biochemistry of vascular smooth muscle plasma membrane as an important factor in the initiation and maintenance of hypertension in rats. Blood Vessels $16: 259-268,1979$.

Kwan, C.Y. and Daniel, E.E. Biochemical abnormalities of venous plasma membrane fraction isolated from spontaneously hypertensive rats. Eur. J. Pharmacol. $75: 321-324,1981$.

Laher, I. and Triggle, C. The relationship between the elevated blood pressure of the spontaneously hypertensive rat and the chemical sensitivity of smooth muscle to adrenergic agents. Can. J. Physiol. Pharmacol. 62:94 - 100, 1984.

Lais, L.T. and Brody, M.J. Vasoconstrictor hyperresponsiveness: an early pathogenic mechanism in the spontaneously hypertensive rat. Eur. J. Pharmacol. 47:177-189, 1978.

Longhurst, P.A. and Head, R.J. Responses of the isolated perfused mesenteric vasculature from diabetic rats: the significance of appropriate control tissues. J. Pharmacol. Exp. Ther. 235:45 - 49, 1985.

Lowry, O.H.; Rosebrough, N.J.; Farr, A.L.; and Randa11, R.J. Protein measurement with the folin phenol reagent. J Biol. Chem. 193:265$275,1951$. 
Macleod, K.M. The effect of insulin treatment on changes in vascular reactivity in chronic, experimental diabetes. Diabetes 34:1160 $1167,1985$.

Madia, A.M.; Rozovski, S.J.; Kagan, H.M. Changes in lung lysyl oxidase activity in streptozotocin diabetes and in starvation. Biochem. et Biophys. Acta. 585:481 - 487, 1979 .

Moulds, R.F.W. Techniques for testing isolated blood vessels. Gen. Pharmacol. 14:47-53, 1983.

Mulvany, M.J. Do resistance vessel abnormalities contribute to the elevated blood pressure of spontaneously hypertensive rats. Blood Vessels 20:1 - 22, 1983.

Mulvany, M.J.; Aalkjaer, C.; Christensen, J. Changes in noradrenaline sensitivity and morphology of arterial resistance vessels during development of high blood pressure in spontaneously hypertensive rats. Hypertension 2:664 - 671, 1980.

Mulvany, M.J.; Hansen, P.K.; Aalkjaer, C. Direct evidence that the greater contractility of resistance vessels in spontaneous hypertensive rats is associated with a narrowed lumen, a thickened media, and an increased number of smooth muscle cell layers. Circ. Res. 43:854-864, 1978.

Mulvany, M.J.; Korsgaard, N.; Nyborg, N. Evidence that the increased calcium sensitivity of resistance vessels in spontaneously hypertensive rats is an intrinsic defect of their vascular smooth muscle. Clin. Exp. Hypertens. 3:749 - 761, 1981.

Mulvany, M.J. and Nyborg, N. An increased calcium sensitivity of mesenteric resistance vessels in young and adult spontaneously hypertensive rats. Br. J. Pharmacol. 71:585 - 596, 1980. 
Newman, R.A. and Langner, R.O. Age-related changes in the vascular collagen metabolism of the spontaneously hypertensive rat. Exp. Geronto1. 13:83-89, 1978 .

Nilsson, H. and Mulvany, M.J. Prolonged exposure to ouabain eliminates the greater noradrenaline-dependent calcium sensitivity of resistance vessels in spontaneously hypertensive rats. Hypertension $3: 691-697,1981$.

Noon, J.P.; Rice, R.T.; Baldessanne, R.J. Calcium leakage as a cause of high resting tension in vascular smooth muscle from spontaneously hypertensive rats. Proc. Natl. Acad. Sci. 75:1605 - 1607, 1978.

Olivetti, G.; Melissari, M.; Marchetti, G. Quantitative structural changes of the rat thoracic aorta in early spontaneous hypertension. Circ. Res. 51:19-26, 1982.

Ooshima, A.; Fuller, G.C.; Cardinale, G.J.; Spector, S.; Udenfriend, S. Increased collagen synthesis in blood vessels of hypertensive rats and its reversal by antihypertensive agents. Proc. Natl. Acad. Sci. USA 71;3019-3023, 1974.

Owen, M.P. and Carrier, G.O. Alteration in vascular smooth sensitivity to vasoconstrictor agents by streptozotocin-induced diabetes. Proc. West. Pharmacol. Soc. 22:363 - 366, 1979.

Owen, M.P. and Carrier, G.O. Calcium dependency of norepinephrineinduced diabetes. J. Pharmacol. Exp. Ther. 212:253-258, 1980.

Pfaffman, M.A. The effects of streptozotocin-induced diabetes and insulin-treatment on the cardiovascular system of the rat. Res. Comm. Chem. Path. Pharmaco1. 28:27- 41, 1980.

Pfaffman, M.A.; Ball, C.R.; Darby, A.; and Helman, R. Insulin reversal of diabetes-induced inhibition of vascular contractibility in the rat. Am. J. Physiol. 242:14490 - 14495, 1982. 
Pfaffman, M.A.; Helman, R.; Darby, A. Contractile and relaxing activity of arterial smooth muscle from streptozotocin-diabetic rats. Res. Comm. Chem. Path. Pharmacol. 30:283 - 299, 1980.

Rioux, F. and Berkowitz, B.A. Role of the thyroid gland in the development and maintenance of spontaneous hypertension in rats. Circ. Res. 40:306-312, 1977.

Scarborough, N.I. and Carrier, G.O. Increased $\alpha_{2}$-adrenoreceptor mediated vascular contraction in diabetic rats. J. Auto. Pharmacol. $3: 177-183,1983$.

Scarborough, N.L. and Carrier, G.O. Nifedipine and alpha adrenoceptors in rat aorta. I. Role of extracellular calcium in alpha-1 and alpha-2 adrenoceptor-mediated contractions. J. Pharmacol. Exp. Ther. 231:597-602, 1984a.

Scarborough, N.L. and Carrier, G.O. Nifedipine and alpha adrenoreceptors in rat aorta. II. Role of extracellular calcium in enhanced alpha-2 adrenoceptor mediated contraction in diabetes. J. Pharmacol. Exp. Ther. 231:603 - 609, 1984b.

Schneir, M.; Bowersox, J.; Ramamurthy, N. Response of rat connective tissue to streptozotocin diabetes. Biochem. et Biophys. Acta. $583: 95-102,1979$.

Sen, S.; Smeby, R.R.; Bumpus, F.M. Renin in rats with spontaneously hypertension. Circ. Res. 31:876-880, 1972.

Shibata, S.; Hurahasi, K.; Kuchii, M. Possible etiology of contractile impairment of vascular smooth muscle from spontaneously hypertensive rats. J. Pharmaco1. Exp. Ther. 185:406 - 417, 1973.

Smith, T.L. and Hutchins, P.M. Central hemodynamics in the developmental stage of spontaneous hypertension in the unanesthetized rat. Hypertension 1:508 - 517, 1979. 
Somani, P.; Singh, H.P.; Saini, R.K.; Rabinovitch, A. Streptozotocininduced diabetes in the spontaneously hypertensive rat. Metabolism 28:1075 - 1077, 1979 .

Spector, S.; Fleish, J.H.; Maling, H.M.; and Brodie, B.B. Comparison of the reactivity of vascular smooth muscle from normotensive and hypertensive rats. Science 166:1300 - 1301, 1969.

Thomas, P.K.; Jefferys, J.G.R.; Sharma, A.K.; Bajada, S. Nerve conduction velocity in experimental diabetes in the rat and rabbit. $J$. Neuro1. Neurosurg. Psychiatry 44:233-238, 1981.

Warshaw, D.M.; Mulvany, M.J.; Halpern, W. Mechanical and morphological properties of arterial resistance vessels in young and old spontaneously hypertensive rats. Circ. Res. 45:250 - 259, 1979.

Webb, R.C. and Bohr, D.F. Recent advances in the pathogenesis of hypertension: Consideration of structural, functional, and metaboIic vascular abnormalities resulting in elevated arterial resistance. Am. Heart J. 102:251-264, 1981.

Webb, R.C. and Vanhoutte, P.M. Cocaine and contractile responses of vascular smooth muscle from spontaneously hypertensive rats. Arch. Int. Pharmacodyn. Ther. 253:241 - 256, 1981.

Winer, B.J. Statistical principles in experimental design. McGraw Hill Inc. pp185 - 196, 1971.

Young, J.B.; Mullen, D.; Landsberg, L. Caloric restriction lowers blood pressure in the spontaneously hypertensive rat. Metabolism $27: 1711-1714,1978$. 